\title{
Chapter 3 \\ Pedro Sánchez Ciruelo. A Commentary \\ on Sacrobosco's Tractatus de sphaera with a Defense of Astrology
}

\author{
Tayra M. C. Lanuza Navarro
}

\begin{abstract}
This paper focuses on the figure of the Spanish scholar Pedro Sánchez Ciruelo (ca. 1470-1548), who published a commentary on Johannes de Sacrobosco's Sphaera in 1498. The aim of this study is to analyze the defense of astrology that Ciruelo prepared for the preface of his commentary in order to show that this praise of astrology represents a significant part of the scholar's intellectual interests, which remained constant throughout his career. It is possible to get a richer understanding of Ciruelo's defenses of astrology in several of his works by placing them in their own specific context: the first one in the context of the prohibition of Simon de Phares's activities in Paris in 1494, and the second one in Europe in the first decades of the sixteenth century, during which those interested in astrology were mainly concerned with Pico della Mirandola's Disputationes and its consequences for the discipline.
\end{abstract}

\section{Introduction ${ }^{1}$}

The Spanish scholar Pedro Sánchez Ciruelo (ca. 1470-1548) published his commentary on Johannes de Sacrobosco's (died ca. 1256) Tractatus de sphaera, Uberrimum Sphere mundi commentum, in 1498 (Ciruelo 1498). At that time, he was in Paris, teaching mathematics and studying theology at the University of Paris. Ciruelo had arrived in Paris in 1492, after having spent 10 years at the University of Salamanca. There he was trained at the faculty of arts in the quadrivium, particularly in astrology, as well as in moral and natural philosophy and metaphysics, while teaching disciplines of the trivium simultaneously.

\footnotetext{
${ }^{1}$ The research for this article was funded by the 2016-1017 Fellowship Programme of the Herzog August Bibliothek (Wolfenbüttel) and by the Mellon Fellowship (2014-2015) at Villa I Tatti, The Harvard University Center for Italian Renaissance Studies.
}

T. M. C. Lanuza Navarro $(\bowtie)$

Instituto de Historia de la Medicina y de la Ciencia "López Piñero." Universitat de València,

Valencia, Spain

e-mail: tayra.lanuza@uv.es 
Many aspects of Ciruelo's commentary on the Sphaera are of interest. First, his insertion of the fourteen Questions on the Sphere of Pierre d'Ailly (1351-1420) to complement his own comments and his additions to some of the subjects treated in the text, such as the definitions of the sphere, the number of celestial spheres, or the rise and setting of the signs. Also, the dialogue at the end of the work, where he discussed the role of authorities in a discipline, and his decisions when writing the commentary. And his defense of the certainty of mathematics, and of astrology within the mathematical sciences.

In this paper, I am going to focus particularly on this last aspect, Ciruelo's defense of astrology in the preface of his commentary on Sacrobosco. However, I will also refer to his inclusion of Pierre d'Ailly's Questions, to some of the issues he discussed in the comments in addition to what was originally in the Tractatus de sphaera, and to some of his explanations in the dialogue, which are related to his interest in astrology. One of the objectives of this paper is to show that Ciruelo defended this discipline from the beginning of his career, while in Paris. Another aim is showing that the preface of the Sphaera is not an isolated piece. The text of the preface in praise of astrology represents a significant part of this scholar's intellectual interests, which remained constant throughout his career. The arguments he introduced in the Sphaera are present in several of his later works. In 1521, Ciruelo published a complete treatise titled Apotelesmata astrologiae Christianae, in which he reflected on his previous assertions and extended his arguments in defense of astrology (Ciruelo 1521).

Despite several historians' emphasis on Ciruelo's relevance as a scholar, the studies considering his figure and works have passed over his astrological ideasmentioning this part of his intellectual endeavors as an afterthought, if not completely dismissing or ignoring it (Albares 1996; Ayala 1993; Rodríguez Vidal 1981; Lorente Pérez 1921; Flórez et al. 1989, 1990). ${ }^{2}$ Theology and becoming a respected theologian were the main focuses of his career. ${ }^{3}$ However, astrology and the mathematical sciences in general were indeed some of Ciruelo's scholarly interests.

This paper concentrates on his astrological interests for two reasons. On the one hand, ignoring the influence that the mathematical sciences and astrology had on his career-as is the trend to date-misrepresents his intellectual ventures. On the other hand, I argue, his theological interests were not separated from his astrological ideas. His aim of establishing a clear definition of what constituted a Christian astrology and of differentiating it from non-orthodox practices and superstition, following the Thomistic tradition, was strongly linked to his theological ideals. Both aspects need to be taken into account to understand Ciruelo's writings, and specifically the preface to Sacrobosco as he wrote it in the Paris edition of 1498.

\footnotetext{
${ }^{2} \mathrm{An}$ exception to the attitude of passing over Ciruelo's astrological ideas is Lou Ann Homza's study, which is focused on Ciruelo's religious attitudes and theological works, and therefore does not delve into his astrological interests. See (Homza 1992, 2000).

${ }^{3}$ (Ciruelo 1521, f. A2r): "divinam theologorum facultatem..., ad quam totis praecordiis aspirabat."
} 


\section{Social and Intellectual Background}

Pedro Sánchez Ciruelo was born in the town of Daroca, in the kingdom of Aragon, between 1460 and 1470. Daroca was not a small village in a remote area, as it has been represented in previous studies related to this scholar. It was a city of political, military, and administrative significance for the kingdom, albeit one of small size (Rodrigo Esteban 1999, 11). Daroca was one of the ten biggest towns in Aragon, which ruled a community of villages around it, and by 1495 the census listed 482 fuegos, or ca. 2.410 inhabitants (Serrano Montalvo 1995-1997). It had a weekly market and three prosperous annual trade fairs (Rodrigo Esteban 1999, 14, 27; Mateos Royo 1997). It had a collegial cathedral and an arts study particularly relevant to Ciruelo's career.

Both his family and the Darocense Study of Arts played a significant role in Ciruelo's later ambitions. In the biographical information he provided in the prologue to the astrological work Apotelesmata, Ciruelo stated that he was an early orphan, and that he was poor and alone in the world. ${ }^{4}$ This was hardly the case, not only because a good number of relatives were alive and living in the city of Daroca or the neighboring town of Molina during the 1460s and 1470s (Homza 1992, 24), but also because of the cost of education. ${ }^{5}$ Each student had to pay an annual tax to be admitted to the Study (which was twenty-eight sueldos in 1525), and although students from Daroca were exempt from paying the five sueldos due to the director, and probably also from paying the monthly payment of thirteen more for food and lodging if they did not use it, Ciruelo would hardly have been able to go through the years of schooling without family help or patronage. ${ }^{6}$

Daroca's Studium Artibus had been assigned a master to teach "Arts, Logic, and Nature" from 1381 on, as well as a teacher of theology from the local Franciscan convent (Rodrigo Esteban 2004, 144). Even if it was referred to as Estudio General in the royal approval of 1381, it is difficult to know to what extent education there went beyond that of a regular grammar school. It was, in any case, the place where the members of the city oligarchy received their education. Sons of merchants and liberal professionals made up most of the student body, but members of more modest social groups were not unheard of. Ciruelo's family does not seem to have been wealthy, as the professions mentioned in the Inquisitorial files are the likes of

\footnotetext{
${ }^{4}$ (Ciruelo 1521, f. A2r): "mihi humili solo nato, omni etiam humano auxilio parentum et patriae destituto."

${ }^{5}$ Even if Ciruelo's paternal grandparents (Francisco Sánchez Ciruelo and his wife) and his parents (Hernán Ciruelo and his wife) had died when he was a child, he could count with his two paternal uncles (Bartolomé and Alonso Ciruelo) and also an aunt (Francisca) to take him in, as well as his brothers Bartolomé and Jorge, and maybe a sister. He had also, or would later have, several cousins and nephews.

${ }^{6}$ On the cost of education in Daroca, see (Mateos Royo 2002).
} 
shoe-maker (his uncle Bartolomé) and "meat cutter" (his cousin Francisco). ${ }^{7}$ So, it would seem he was not really alone in the world, but was probably more or less poor. It is true, however, that he was not the only member of the family to attend university. Whether his studies and those of his brother Bartolomé, who ended up as "maestre" in Alcalá, were paid by his relatives, by the ecclesiastical authorities, or by the city council, which had an effective influence over the Arts Study, is unknown.

Ciruelo's preface to the Apotelesmata was of course an exercise in self-promotion, in self-fashioning, as were many dedicatory letters, introductions, prefaces, and prologues in the period. ${ }^{8} \mathrm{He}$ was creating an image of himself in a piece addressed to the professors of his alma mater, the University of Salamanca. In that image, he presented himself as a successful mathematician and theologian who had overcome hard beginnings for the sake of knowledge. ${ }^{9} \mathrm{He}$ also made a point of explaining that he had funded his university studies by teaching a discipline while studying another one: he used his knowledge of the trivium to teach dialectics in Salamanca while he took the courses to become a Master of Arts, and then used his knowledge of mathematics and astrology to teach in Paris while he studied theology.

In promoting himself as a self-made scholar, as an expert in orthodox doctrine, and as the right person to consult when it came to deciding about astrological practices, Ciruelo was also avoiding mentioning his relatives, maybe because of their converso origins. ${ }^{10}$ He was a descendent of Jews and of judaizers, according to the Inquisitorial files. His grandfather, Francisco Sánchez Ciruelo, had been condemned by the Inquisition for apostasy. His uncle Bartolomé was a confeso, that is, he was a Catholic who had confessed reverting to Jewish practices or beliefs. ${ }^{11}$ The sons of Bartolomé, Ciruelo's four cousins Benito, Cristóbal, Francisco and Pero, had been forbidden to work in public positions for this reason, making it clear that the family had Jewish ancestors. In 1553, after Ciruelo's death, the Inquisition prosecuted his cousin Benito for heretical blasphemy, and also his nephew Juan Ciruelo, son of his cousin Cristóbal (via his other uncle Alonso), for insulting the labor of the Inquisitors. ${ }^{12}$

\footnotetext{
${ }^{7}$ The genealogy of the family has been preserved because of the trials of the Inquisition of his nephew Juan and his cousin Benito in 1553, both of whom mentioned Ciruelo during the lawsuit. Albares presented Ciruelo's family as wealthy, but the Inquisitorial files do not seem to support such an assessment (Albares 1996, 181).

${ }^{8}$ For recent considerations of self-fashioning in the Early Modern University, see the articles in (Kirwan 2016).

${ }^{9}$ The whole sentence was written to present his 'avid search' for knowledge and early struggles: "ut litteras a me quasi fugientes toto pene orbe avidissime persequerer, mihi humili solo nato, omni etiam humano auxilio parentum et patriae destituto foret nimium difficile" (Ciruelo 1521, f. A2r).

10 "He seems to have tried deliberately to mislead his audience about his family," as put by Lou Ann Homza (1992, 24).

${ }^{11}$ The files of the trials of the grandfather, Francisco Sánchez Ciruelo, and of his wife, whose name does not appear but is also mentioned as a judaizer, as well as the file of the trial of Bartolomé Ciruelo, confeso, have not been found to date.

${ }^{12}$ The files are at the Archivo Diocesano de Cuenca, Inquisición, leg. 193, exp. 2175 and 2181. The records of these two trials were summarily described by (Homza 1992, 24-27).
} 
There is no way to know if this family history was one of the motivations behind Ciruelo's insistence in Catholic orthodoxy, or his determination to become a respected theologian and to obtain ecclesiastical positions, which was not unusual among members of converso families (Homza 1992, 101-02). What is certain, however, is that he kept ties with his family and with Daroca throughout most of his life.

After his years in Paris, he returned to Daroca on several occasions to stay for months or years. The significance of the Darocense Study of Arts for him is attested to by his acceptance of the study's director position, as well as the way he managed to coordinate this position with his chair at the University of Alcalá for nearly 20 years.

The first time he accepted the position seems to have been at the end of 1499, when he was still supposed to be in Paris, but after only a few months he renounced and left Daroca (Rodrigo Esteban 2004, 146). He might have gone back to Paris, as it is unknown where he was up until his appointment as professor of philosophy at the College of San Antonio de Portaceli-which also made him canon at the cathedral of Sigüenza-from 1502 to 1505 (Lorente Pérez 1921, 276). Then the city council of Daroca, in agreement with the archbishop of Zaragoza, in whose power lay the appointment of the director of the Study of Arts, offered him the position again. Ciruelo accepted it, as well as the later offer to become the teacher of theology, which improved his salary. His presence as a teacher in Daroca is supposed to have caused the huge increase in the number of students in 1505, which spiked to 150 from around 30 in 1496 and 1499 (Mateos Royo 2002, 131).

He remained as maestro mayor of the Study for four academic courses, during which he worked to obtain from the city council funding to make reforms and improvements to the buildings of the school, and wrote new statutes for the institution (Rodrigo Esteban 2004; Mateos Royo 2002). After his appointment as professor of Thomistic theology at the University of Alcalá de Henares in 1510, he did not quit his teaching position in Daroca.

Ciruelo managed to remain linked to the Study of Arts of his hometown for many more years. He continued to teach at least part-time in Daroca between 1508 and 1516. By dividing his salary with two assistants and often asking the city council for permissions and leaves, he combined these positions with the chair in Alcalá, with the administration of the vicariate in one of the villages of Daroca (Cuencabuena), and with preaching occasionally in Zaragoza (Rodrigo Esteban 2004, 152). He was also involved in the church of Santo Domingo in Daroca, where his brother Bartolomé was the vicar, after they both had been racioneros (canons with right to portion) there for some years.

He definitely left his positions at the Study of Daroca, from which he had been mostly absent for some years already, in 1523, but his links with Daroca and the Study were never forgotten. He went back there in 1524 when his brother died, and in his own testament he donated to the city 400 sueldos for works and maintenance of the Study of Arts (Rodrigo Esteban 2004, 153). 


\section{University Training and Works}

Ciruelo's studies at the University of Salamanca, where he arrived around 1482, seem to have inclined him towards logic and the mathematical sciences, and initiated his interest in astrology. He found in Salamanca an intellectual environment with a concentration on astronomy and astrology, strongly influenced by the figure of Abraham Zacut (1452-ca. 1515) and his astronomical tables, even after Zacut left the city in 1485 (and the country in 1492, forced by the expulsion of the Jews). Zacut wrote two of his astrological works, the Tratado breve de las influencias del cielo (Brief treatise on the influences of heavens) and De los eclipses del sol y la luna (On the eclipses of the sun and the moon), in 1486, not long after leaving Salamanca. These were also well known among professors and students at Salamanca, as Zacut always stayed in contact with his colleagues, who were professors at the university. The first translator of Zacut's Great Composition, later known as the Almanach perpetuum, including the tables and the canons to use them, was Juan the Salaya (ca. 1450-ca. 1524). Salaya was teaching logic while Ciruelo studied at Salamanca, meaning he taught Ciruelo one of the disciplines on which he later focused. Before taking the chair of logic, which he obtained in 1469, Salaya had been the professor of astrology since 1464.

The professors of the chair of mathematics and astrology who taught in the last two decades of the century followed Zacut's and Salaya's path. Besides Salaya's lectures on logic, Ciruelo attended the lectures on astrology by one of them, Diego de Torres (ca. 1435-1496), who was the professor from 1482 to 1496 . He also met and admired the subsequent professor, Rodrigo Vasurto (ca. 1470-1507), who had the chair of astrology from 1496 to 1504, and who might have previously been the professor of natural philosophy. He wrote a work on the calendar, and also a Praxis pronosticandi in 1497 (Flórez et al. 1989, 233-38; Thorndike and Kibre 1963, 504). Diego de Torres wrote an astrological commentary, which remained manuscript, and he seems to have been one of the translators of Sacrobosco's Sphaera, writing a version in Spanish around 1484 (Flórez et al. 1988, 22, 1989, 66-75; Burgueño 2009, 8; Gómez Martínez 2006). ${ }^{13}$ Ciruelo's appreciation of Zacut's and Vasurto's knowledge is mentioned in several of his texts. In the prefatory letter of his 1521 work Apotelesmata, he referred to Zacut among those who had studied the sphere and created astronomical tables, praising the Almanach, which gave easy access to the information on the course, place, and aspects of the fixed stars and the planets. ${ }^{14}$

\footnotetext{
${ }^{13}$ The Spanish translation by Torres of the Sphaera is found in manuscript 3385 at the Biblioteca Nacional de Madrid, ff. 189r-199v, and the commentary as well. For other translations of Sacrobosco's Sphaera, see (Crowther et al. 2015). For translations into Spanish, and also into Portuguese (Chap. 7), and for the Latin version of André de Avelar and the genre of the Reportorios de los tiempos in Spain and Portugal, see (Chap. 10).

${ }^{14}$ (Ciruelo 1521, a2v): "Si eruditioni sphericae a nobis accepte Almanach cum perpetua tum et temporalia superaddant, quae omnes cursus, situs, aspectus, siderum sive fixorum sive errantium brevissime diurneque ostendunt sine ambagibus ac laboribus excessivis. Haec eum Zacutus vester Salmanticensis, Jonannes Nurembergensis et quidam alii recentiores divino quodam ingenio elaborata posteris reliquerunt."
} 
In the Dialogue at the end of the commentary to the Sphaera, he expressed his admiration for Vasurto, "an Alphonse of our own times."15

With this mathematical and astrological background, Ciruelo moved to Paris in 1492 with the aim of studying theology. The intellectual circle he joined there has been studied with an emphasis on those known as the Spanish calculatores, a group of mathematicians who later tried to integrate mathematical knowledge into physical science in Spanish universities. They were also students of theology in Paris. This group included Juan Martínez Silíceo (1477-1557) and Fernando de Encinas (died 1523), and later Gaspar Lax (1487-1560) and Fernán Pérez de Oliva (ca. 1494-1531). ${ }^{16}$

Ciruelo also found in Paris a scholarly milieu marked by Jacques Lefèvre d'Étaples's (ca. 1455-1536) vindication of mathematics in his fight against Scotism at the University of Paris, and by his influence on the studies of mathematics and on the printing of mathematical works (Pantin 2013, 23). ${ }^{17}$ Ciruelo was following Lefèvre d'Étaples's example when he printed his commentary to the Tractatus de sphaera only 3 years after the Parisian professor had published his own in 1495. Ciruelo seems to confirm that this was the case in his own words in the new version of the preface to the Sphaera of Sacrobosco that he prepared for publication in Alcalá de Henares in 1526 (Ciruelo 1526). It has been pointed out that Ciruelo seems to have shared some of the ideas expressed by Lefèvre concerning, for instance, the reality of the celestial orbs (in this case, an idea also held by Pierre d'Ailly) (Barker 2011, 15-16) (Chap. 6). The extent to which both shared mathematical notions and natural philosophical ideas on the heavens is a subject still waiting to be explored in depth.

During this period in Paris, Ciruelo published most of his mathematical works: an Arithmeticae practicae in 1495, the Arithmetica Speculativa in the same year, and the Geometria Speculativa by Thomas Bradwardine (ca. 1300-1349) (Ciruelo 1495a, b, c). In 1498, Ciruelo published the commentary on Sacrobosco, which was reprinted in Paris in 1508 and 1515, and in Alcalá in $1526 .{ }^{18}$ His interest in preparing materials for teaching the mathematical liberal arts did not end after he left Paris. His course on them (Cursus quattuor mathematicarum artium liberalium) was published in 1516, when he was back in Spain (Ciruelo 1516).

\footnotetext{
${ }^{15}$ (Ciruelo, 1498, n7r.): "Placeret utique si prius hec Rodericus noster Vasurtus rescivisset, qui ita profunde ut nosti mathematica hec callet ut alter nostris temporibus Alphonsus appareat, adde etiam quod nostri amantissimus est et nisi quod verum cognovisse consuluisset nichil."

${ }^{16}$ On the Spanish calculatores in Paris, see (Wallace 1969, 1981, 79-90; Rey Pastor 1926, 72-81; Villoslada 1938; Calderón 1991, 247-48; Navarro Brotons 2014, 26-28, 58-72). See also (Elie 1950-1951). On a few of Ciruelo's mathematical notions, see (Cajori 1928; Lorente Pérez 1921). On the interest of these Spaniards in logic, see also (Noreña 1975).

${ }^{17}$ On the mathematical context in Paris at the moment, and on Lefèvre's plans for mathematical reform, see (Chap. 2).

${ }^{18}$ Different editions are sometimes mentioned but it does not seem possible to find them. For the editions of the commentaries on Sacrobosco's Sphaera, see the database accessible through the website of the project The Sphere. Knowledge System Evolution and the Shared Scientific Identity of Europe (https://sphaera.mpiwg-berlin.mpg.de).
} 
Later in his life, after his ten years of theological studies in Paris, Ciruelo went back to Spain and in 1510 became professor of theology, in the chair called "of Saint Thomas," at the newly created University of Alcalá de Henares. There, while teaching Thomas Aquinas's (1225-1274) theology and philosophy, Ciruelo published most of his works on logic. These included an edition of Aristotle's (384-322 BCE) logic in 1519 and two commentaries on the Posteriora Analytica in 1528 and 1529 (Ciruelo 1519, 1528). While in Alcalá, he also published his major work on astrology, the above mentioned Apotelesmata, in 1521, as well as an Introductio astrologica in 1523.

Ciruelo would leave the university in 1533 to hold ecclesiastical positions, first in Segovia, and then in Salamanca, where he became the canon preacher of the cathedral. There are no data about him teaching at the university there; however, he certainly continued publishing. This period was focused on religious texts, with sermons, reflections on theological mysticism, and translations of the Bible (Flórez et al. 1990, 18-19; Homza 1992, 175-208). ${ }^{19}$ It was in 1537, while living in Salamanca, that he also published what has been labeled his most mature work on logic, his Summule Petri Hispani (Muñoz Delgado 1967, 197).

The Cursus mathematicarum of 1516 included Bradwardine's Arithmetic and Geometry with some comments extracted from Jordanus Nemorarius (active ca. 1222) and Campanus of Novara (ca. 1220-1296) (Lorente Pérez 1921, 314), as well as John Peckham's (ca. 1230-1292) and Alhacen's (Ibn-al-Haytam, ca. 965ca.1040) Perspective, and the music of Lefèvre d'Étaples, with Boethius's (active ca. 525) theory. ${ }^{20}$ In the prologue of this Cursus, which he dedicated to the rector and scholars of the University of Alcalá de Henares, Ciruelo explained that his intention was to serve the university by providing it with an introduction to the four mathematical doctrines mentioned. To these he seemed to intend to add a fifth piece, an astrological introduction. He referred to this work as already written, explaining that it was a small work on the Sphaera based on Ptolemy's (ca. 100-ca. 160) Almagest, on Zacut's Almanach, "and on our own judicial Quadripartitum and Centiloquium." ${ }^{21}$ Ciruelo's "own Quadripartitum and Centiloquium" are the components of the Apotelesmata Astrologiae Christianae, which he printed in 1521. This seems to suggest that the work, or a shorter earlier version of it for students, was already written in 1516. It could also mean that the 1523 Introductio astrologica listed among his works — of which no copies are left—was this fifth part of the mathematical course, and that it could have been a summary of the Apotelesmata. ${ }^{22}$

\footnotetext{
${ }^{19}$ On Ciruelo's translations, see also (Valle 1999).

${ }^{20}$ On how the Cursus was based on Lefèvre d'Étaples's works, see (Oosterhoff 2018, 108-11).

${ }^{21}$ (Ciruelo 1516, a3r.): "Quinta quoque erit introductio astrologica, quam in sphericum opusculum olim condideram correspondentem Almagesto Claudii Ptholomei clarissimi, et Almanach perpetuum Zacuti Salmanticensis, cum nostro judiciario Quadripartito ac Centilegio."

${ }^{22}$ The work was recorded by (Picatoste Rodríguez 1891, 46-52; Latassa Ortiz 1798, 182-91). See the catalogues of Ciruelo's works in (Navarro Brotons et al. 1999, 94-96; Wilkinson 2010, 128-30).
} 
If this was his intention - to create a fifth book with the basics of astronomy and astrology-it would explain why he did not include such knowledge in the Cursus. ${ }^{23}$

The kind of defense of astrology which Ciruelo decided to include in his commentary on Sacrobosco's Sphaera is different from that of the Apotelesmata. This, I argue, is due to the context in which he wrote each text, not in the sense implied by Thorndike, who asserted that the prohibitions of judicial astrology by the Paris faculty would have prevented him from openly standing in defense of the discipline in 1498 (Thorndike 1941, 275-79), but precisely the opposite. It gave him a reason to place his arguments for astrology in the Sphaera, and these arguments were later the base for the expanded defense constituted by the Apotelesmata. Before discussing this issue, I will describe the actual contents of the preface to the Sphaera, and their relationship to the other elements of the commentary mentioned above.

\section{The Commentary on Sacrobosco's Tractatus de sphaera, the Preface, and It's Context}

Ciruelo's edition of Sacrobosco was composed of three parts. It started with the preface containing the defense of astrology, and it ended with a dialogue discussing what would be a crucial theme in sixteenth century works on natural philosophy: the authority of ancient and highly-esteemed medieval scholars versus new ideas and information.

The central part of the work is composed, as expected, by Sacrobosco's text and Ciruelo's glosses. This is where Ciruelo inserted the fourteen Questions on the Sphere of Pierre d'Ailly. The text of the Questions is placed after Ciruelo's own comments to Sacrobosco. Thus he could introduce issues which were not found originally in the Sphaera, or add later opinions on a subject. Many of them were issues which had been regularly discussed by natural philosophers between the thirteenth and the fifteenth centuries, such as the existence of void, the movement of the primum mobile, the physical existence of the planetary spheres, the necessity of epicycles and eccentrics, the habitability of all zones of Earth, etc. (Grant 1996). Concerning this last issue, Ciruelo introduced in the commentary news on the travels of Columbus, pointing out that the experience of Spanish and Portuguese sailors had shown that there were territories near the equinox which were inhabited. ${ }^{24}$ From the first trip "they brought back with them men of that region," he explained. Ciruelo's description here of the inhabitants of those tropical regions, men who were "not tall but... agreeable...smiling...friendly.... with a dark color" (ceruleo colore) might

\footnotetext{
${ }^{23}$ On the teaching of mathematics in Spanish universities during the sixteenth century, see (Navarro Brotons 1995, 1998, 2006).

${ }^{24}$ (Ciruelo 1498, h2r-h2v): "Cum enim anno Christi domini 1491 illustrissimus hyspaniarum rex Fernandus expertissimos nautas versus occidentem equinoctialem ad insulae quererendas miserit; tandem post quattuor fere menses idem nautae reversi insulas multas sub equinoctiali vel prope dicunt se reperisse. In cuius rei testimonium multa genera avium exquisitissima multasque species aromaticas preciosissimas aurumque et homines illius regionis secum advexerunt."
} 
Fig. 3.1 Illustration of a black man. The printer, Guy Marchand, had previously used this image in the widespread almanac Calendrier des bergers and other works, so its association with the contents of Ciruelo's Sphera is not clear. From (Ciruelo 1498). Biblioteca de Catalunya, Barcelona

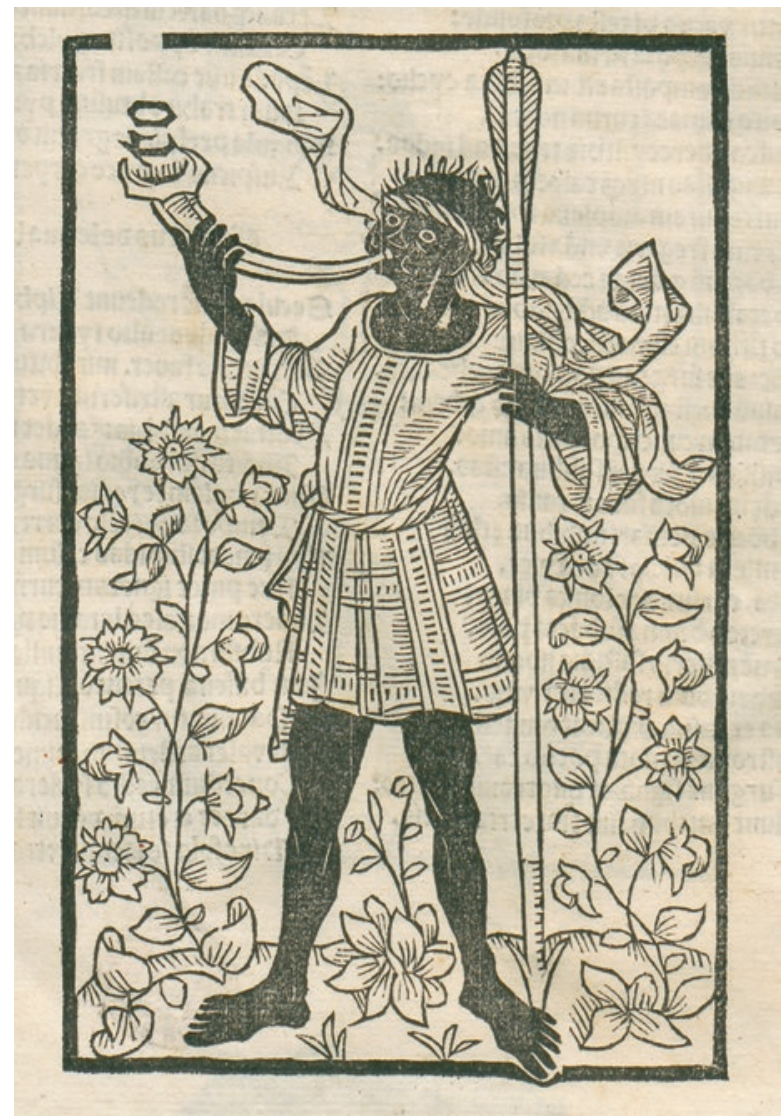

have been the inspiration for the inclusion of the illustration of a black man, placed at the beginning of the work, before his preface (Fig. 3.1). ${ }^{25}$ The decision must have been taken at the printer's workshop. Guy Marchand, who was printing it on behalf of Jean Petit, had previously used the same image in his printed version of the Calendrier des bergers in 1493, and in his edition of Savonarola (1452-1498)'s Revelatio de tribulationibus of $1496 .{ }^{26}$ Whether Marchand decided to reuse the image because he associated Ciruelo's work with the astrological contents of the Calendrier des bergers, or as a call for repentance-as the image seems to be interpreted in Savonarola's work where the image includes the legend "Le maure de sales"-or in relation to the mentioned description, it is difficult to say. In Ciruelo's Sphera, the image was present only in the 1498 edition, not to be found in those of

\footnotetext{
${ }^{25}$ (Ciruelo1498, h2v): "Homines quidem illi non magne stature, sed periocundi, saepius ridentes et bone indolis facile omnibus credentes et aquiescentes, satis ingeniosi, ceruleo colore et capite quadrangulari hyspanis mirabiles apparverunt." The illustration is in fol. a2v.

${ }^{26}$ (Savonarola 1496, a1v). On the role of publishers in the iconographical program of the different editions of the Sphaera in the sixteenth century, see (Chap. 9). On the Calendrier des Bergers, see (Engammare 2008).
} 
1508 and 1515 which were printed by Jean Petit (fl. 1493-1530) in Paris, and it was absent also from the 1526 edition of Miguel de Eguía (1495-1544) in Alcalá.

Initiating his Sphaera with a praise of mathematics was following the tradition of the Boethian claims about their nature and value, and certainly working in the mold of Lefèvre d'Étaples. Actually, Ciruelo started the preface by using the same biblical quotation used sometimes by Lefèvre d'Étaples: Romans, 1:20. ${ }^{27}$ All human sciences provided men with knowledge of God, and a science had to be considered worthier if it did so with more certitude than others, he wrote. ${ }^{28}$ Thus, he explained, mathematical doctrines had to be preferred to all other sciences after theology, because they fulfilled this role, and therefore had superior dignity (Fig. 3.2). ${ }^{29}$ In this first part of the preface, Ciruelo was careful to quote only the Bible and Aristotle, mainly the Metaphysics, through Averroes's (Abū l-Walīd'Aḥmad ibn Muhammad ibn Rušd, 1126-1198) words in some cases. Later natural philosophers and mathematicians, some also editing Sacrobosco's work, would include this same ideathat the study of mathematics and specifically of astronomy led to knowledge of God-among them Oronce Finé (1494-1555) and most famously Philipp Melanchton (1497-1560), who also used this idea to support the legitimacy of astrology (Almási 2014, 10-11). ${ }^{30}$

Other authors, like Nicholas Cusanus (1401-1464), had preceded Ciruelo in insisting on the Aristotelian (Averroistic) idea of the certitude of mathematics and the value of mathematical demonstration (Albertson 2014). These, combined with the also oft-repeated argument that mathematics was superior to other sciences in that it allowed no diversity of opinions, constituted the main ways to praise mathematics in this period, that is, before the 1540s and the burst of debate on the Quaestio de certitudine mathematicarum. ${ }^{31}$ Ciruelo's work illustrate this previous stage of the question, as all three reprints of his commentary to Sacrobosco were published before the onset of that debate. Ciruelo chose this path to later substantiate the nobility and excellence of astrology not only as one of the mathematical sciences, but as superior to all others.

\footnotetext{
${ }^{27}$ Ciruelo's version was: "Invisibilia inquit dei per ea quae facta sunt a creatura mundi intellecta conspiciuntur sempiterna quoque virtus eius et divinitas." (Ciruelo 1498, a3v). On the quote and its meaning in Lefèvre d'Étaples, see (Oosterhoff 2018, 127).

${ }^{28}$ (Ciruelo 1498, a3v): "Ideo sciencia omnis a sapientibus huius seculi humanis parta laboribus viribusque omnipotentis et veri dei aliqualem agnitionem hominibus affert...et tanto scienciam aliquam digniorem existimare oportet quanto altius certiusque deum nobis insinuat."

${ }^{29}$ (Ciruelo 1498, a3v): "Cum igitur in mathematicis doctrinis horum utrumque manifeste appareat: merito post primam philosophiam ceteris humanis scienciis preferende sunt easque dignitate antecedent."

${ }^{30}$ On Finé's edition of the Sphaera see (Chap. 8). On Finé, see (Pantin 2013), and the articles in (Marr 2009). Specifically on the status of mathematics in Finé, see (Axworthy 2009, 2016), and on Melanchton's letter, see (Pantin 1987). On the theological significance of nature in the sixteenth century, see (Crowther-Heyck 2003).

${ }^{31}$ Ciruelo phrased it thus: "In aliis item scienciis propter earum minorem certitudinem doctorum diversitas et opinionum controversia locum habet; in mathematicis vero nequaquam." (Ciruelo 1498, a3v). On the Questio, debated later in the sixteenth century, see (Jardine 1984, 1988, 1998; De Pace 1993; Mancosu 1992, 1996, 8-24; Dear 1995, 34-42; Cozzoli 2007).
} 


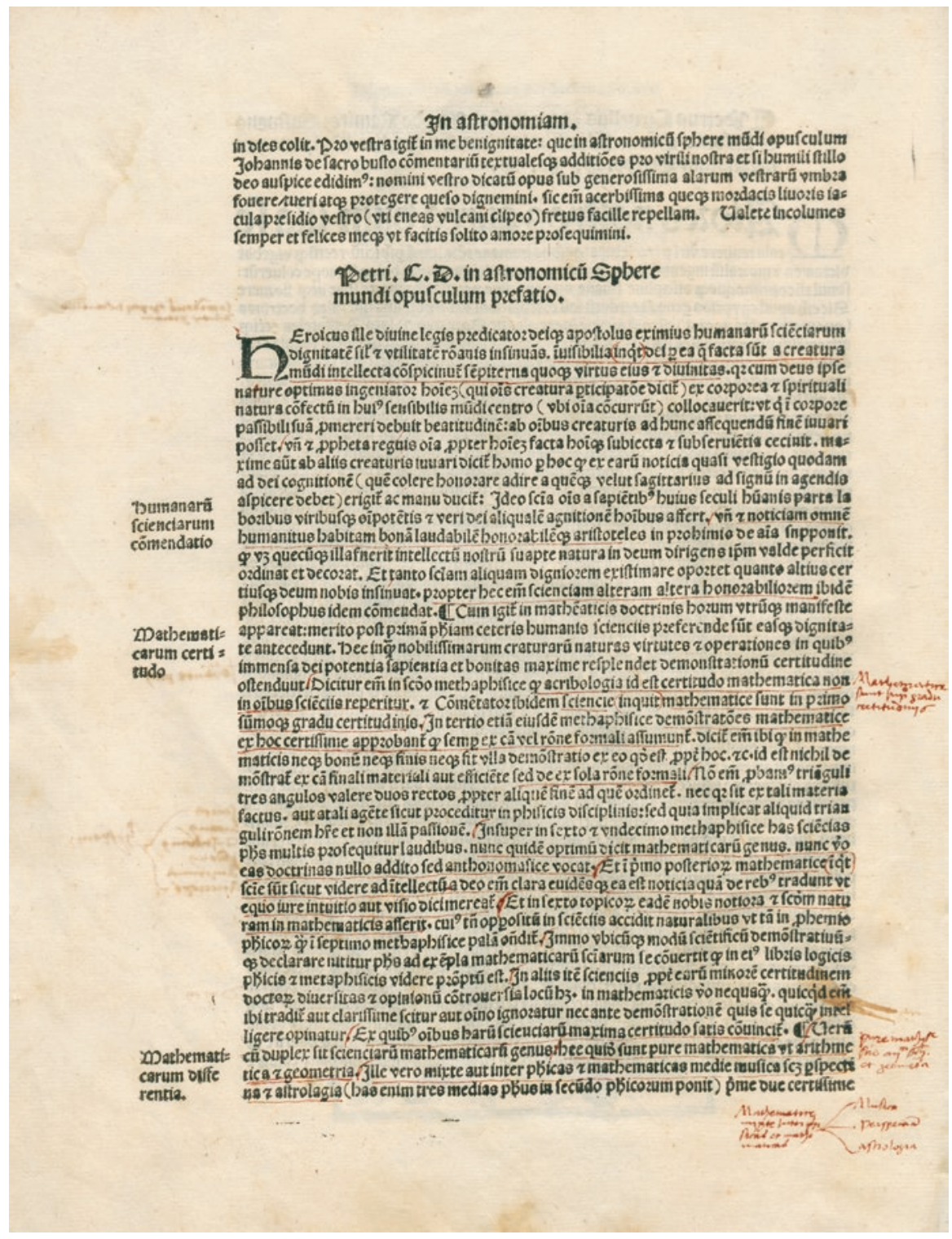

Fig. 3.2 Preface. This first page contains Ciruelo's praise of mathematics as a superior discipline and his discussion on the issue of certitude regarding mathematical doctrines. From (Ciruelo 1498). Biblioteca de Catalunya, Barcelona

This part of the preface closed with Aristotle's categorization of the mathematical disciplines. Those dealing with abstract magnitude (number and quantity) were pure mathematical sciences: arithmetic and geometry. Those concerned with magnitude together with some specific natural matter were subordinate to them: mainly astronomy, astrology, and music, but also perspective and optics in general. These did not 
follow the Aristotelian rule that demonstrations could not jump from one kind of subject matter to another, belonging to what in the medieval period were often called middle (medie), intermediate, or, later on, mixed mathematical disciplines. ${ }^{32}$ Aristotle's classification of the sciences and his discussion about the scientific status of the mathematical disciplines in the Posteriora Analytica and the Methaphysics, both of which Ciruelo cites, were the guides for the differentiation developed by medieval authors. ${ }^{33}$

The distinction between purely mathematical sciences and mathematical disciplines which applied mathematics to physical phenomena was common in scholastic philosophy (Galle 2003, 126-27) and provoked later debates on demonstration within the latter sort (Dear 1995; Laird 2016). Thomas Aquinas had explained that there were purely natural sciences, purely mathematical sciences, and scientiae mediae. The last received abstract principles from purely mathematical sciences and applied them to sensible matter. ${ }^{34}$ On this basis, the Spanish scholar could insist on one of the ideas that appears crucial to his consideration of astrology: that it was demonstrative, like other mathematical sciences, but it also provided information on physical reality. He would reemphasize the importance of this Aristotelian classification again in the dialogue that closed the Sphaera, and in some of his other works. To further support this part of the preface, Ciruelo had included Pierre d'Ailly's Questio Prima at the beginning of the commentary. Ailly's commentary on the first part of Sacrobosco's first chapter (on the shape of the world) was partly focused on the nature of mathematics and how astrology was part of the mathematical sciences. The bishop's explanation of the two kinds of mathematical disciplines and the nature of perspective, music, and astronomy was summed up in the margin with the words "mathematice medie vel mixte" (Ciruelo 1498, b3v). In this part d'Ailly also explained the different branches of astrology, and what astrologia iudiciaria was. ${ }^{35}$

Because astrology and the other two mixed mathematical sciences were also physical disciplines, they were nobler, as they transmitted knowledge about natural things with the certitude of mathematical demonstration. ${ }^{36}$ In the dialogue at the end

\footnotetext{
${ }^{32}$ Astronomy, astrology, music, perspective, and optics would be the disciplines which during the seventeenth century debates, at least from the publication of Francis Bacon's Advancement of learning (if not earlier), were called "mixed mathematics." See (Brown 1991; Dear 1995, 38-39).

${ }^{33}$ Aristotle, Posterior analytics I and II, particularly I.7; Aristotle, Metaphysics XI and XIII, particularly XIII.3. Also, Aristotle, Physics, I.1 and II.2. See (McKirahan 1978, Mandosio 1994).

${ }^{34}$ In the commentary on the Physics. See (Gagné 1969; Ribeiro do Nascimento 1974; Laird 2016).

${ }^{35}$ (Ciruelo 1498, b3v): "Quinta parts considerat de effectibus consequentibus coniunctiones vel oppositiones vel aspectus corporum celestium. Et ista vocatur astrologia iudiciaria, et etiam potest proprie vocari astrologia...."

${ }^{36}$ (Ciruelo 1498, a4r): "Hec igitur tres omnium particularium scienciarum nobilissime sunt, quia in eis simul phisice et mathematice pericie pulchritudo reperitur, qua enim phisice sunt obiecti pollent nobilitate, qua vero mathematice demonstrationis gaudent certitudine. Unde rerum naturalium non inductive et debiliter (ut alie sciencie permulte) sed demonstrative et scientifice cognitionem servata materie qualitate tradunt." The idea that among the branches of natural philosophy, astronomy was superior because of the perfection of its subject matter and because of the certainty of its mathematical nature, was a conclusion authors extracted from Aristotle's Metaphysics, XII, 8 (Jardine 1988, 145).
} 
of the work, he repeated that astrologia, in this case meaning astronomy, was "physical more than mathematical," as it studied the movements of the celestial bodies. ${ }^{37}$ The question of categorizing astronomy and astrology this way appeared in other prefaces to Sacrobosco's Sphaera (Almási 2014, 11). It was this mixed nature between physics and mathematics that made the science of the stars superior to other disciplines, a notion not unfamiliar to the context of sixteenth century astronomy, nor to later debates about the status of the discipline and the identity of the astronomer (Biagioli 1989, 1993, 211-44; Westman 1980, 2011, 202-9, 353-55).

The core of the preface focused on four arguments to support the assertion of the perfection of astrology among mathematical disciplines. These arguments would be reused by astrologers during the sixteenth and seventeenth centuries in defense of their art. The same questions about the dignity and nobility of astronomy and the value of astrology, although with different views concerning the last, were discussed later, for instance, by Francesco Capuano da Manfredonia (active fifteenth century) (Chap. 4).

Ciruelo's piece proceeded from the Aristotelian idea that the dignity of astrology/astronomy was elevated because its object of study, the celestial bodies, was superior. ${ }^{38}$ This was the first place Ciruelo cited Ptolemy, and he was careful not to quote only the Almagest, but to mention the Quadripartitum as well. This delivered the message that his praise was not only for mathematical astronomy and the study of the movements of the heavens, but for the whole science of the stars, including the study of the influences of the heavens, i.e., astrology. Ciruelo had started using the term astrologia for the science of the stars in general. But he made sure to keep readers from interpreting his defense as strictly applying to astronomy, the study of the movements, and not necessarily to astrology, the discipline focused on influences. He used a good number of quotes from Aristotle's works on celestial bodies as causes of natural events on earth, on the hierarchical classification of bodies in nature, and on the inferior world as being ruled by the superior bodies of the heavens. Astrology, he insisted — and he had made clear he meant the study of influences as much as any other aspect of the science of the stars-exceeded all other disciplines, because the other disciplines studied only corruptible bodies; they were not focused on the study of the heavens and the whole universe. ${ }^{39}$

Ciruelo continued by stressing that astrology also had to be praised because of the method it used, the way it established knowledge. This was where he discussed the key issue of the study of causes. According to the Aristotelian principles, a discipline only qualified as scientia if it concerned the study of causes. The debate of

\footnotetext{
${ }^{37}$ (Ciruelo 1498, n5v): "Astrologiam, o amice, Aristoteles phisicam magis quam mathematicam ostendit, quod scilicet supremorum corporum motus potissimum perscrutatur."

${ }^{38}$ (Ciruelo 1498, a4r): "Quod enim rei digeste dignitate astrologia omnes alias particulares sciencias excedat hec res indicio erit, quia ut Ptholemeus in primo et Almagesti et Quadripartiti habet hec sciencia celorum et ornatissimorum astrorum naturas virtues motus et effectus speculator."

${ }^{39}$ (Ciruelo 1498, a4r): "Cum igitur alie omnes discipline aut nullam aut non ita propriam celorum et totius universi faciant theoriam sed earum precipua intentio circa corruptibilia versetur corpora palam est astrologiam eas omnes hac ex parte antecellere."
} 
the quaestio de certitudine mathematicarum, very much focused on this issue as it pertained to mathematics, had not started yet-it developed later, in the sixteenth century. However, scholars were aware that a defense of a discipline had to deal with this question, particularly in the case of a mathematical discipline. Here, the assertion that it was a mixed mathematical discipline played the central role. As a partly physical science, it departed from the effects to get to know the causes. Ciruelo linked this to the previous argument by stressing that astrology investigated the highest causes. ${ }^{40}$ The argument was rounded off with the assertion that astrology comprehended the infallible demonstrations of the other four mathematical disciplines. It used geometry to understand the dimensions of the heavens and arithmetic to know the ratio and rules of the celestial movements. The courses of the heavens, Ciruelo stated, were connected with a musical harmonic proportion, and astrology also made use of perspective to understand the influential rays and the aspects of the stars (which had effects on earth and on men). ${ }^{41}$ Thus "the procedure of this science is more certain than the ways of all the other [sciences]," he concluded. ${ }^{42}$ The fact that the first part of the preface was a praise of the disciplines of the quadrivium gave strength to this part of Ciruelo's defense of astrology.

The next argument was a traditional one: there had been great scholars who studied astrology in the past, and their intellectual relevance and their piety was proof of astrology's nobility. Using a history of mathematics, astronomy, or any scientific discipline was a strategy developed to justify its study and give legitimacy to it, which both humanist and scholastic writers used (Grafton 1997; Goulding 2006). The authors used such narratives to distinguish the acceptable from the unacceptable parts of their discipline, the licit from the illicit (Popper 2006), which was particularly fitting for a defense of astrology designed in the context of a prohibition such as existed in Paris after the Simon de Phares (1444-ca. 1499) affair (see below). Highlighting ancient authorities for mathematics - and astrology-the authors tried to contribute to the process of legitimizing such knowledge (Popper 2006, 106). This was actually the path chosen by Simon de Phares to defend astrology when some of his practices and books on astrology were condemned by the Parliament and by the University of Paris's faculty of theology. He had intended to radically distinguish magical, divinatory, and superstitious arts from astrology, an objective he shared with Ciruelo. He decided to describe the historical precedents,

\footnotetext{
${ }^{40}$ (Ciruelo 1498, a4r): "Ex suo etiam procedendi modo certissimo astrologia super omnes humanas sciencias laudatur, siquidem enim vigoris modus habet procedendi phisicus ex effectibus scilicet ad causas perveniendo hoc in astrologia que partim phisica est tanto excellentiori modo reperitur quanto altiores causas suo processu investigat."

${ }^{41}$ On musical harmony in nature, and the spheres, see (Voss 1998).

${ }^{42}$ (Ciruelo 1498, a4r-a4v): "Infallibilem etiam demonstrandi modum aliarum quattuor mathematicarum hec sola comprehendit. Ibi enim geometricis theorematibus...celorum et stellarum...comprehenduntur et mesurantur, motuum quoque celestium norme arithmeticis numerorum rationibus cognoscuntur. Tot etiam tamque differentes celorum cursus armonica musicave proportionalitate connectuntur...Non desunt etiam perspective demonstrationes han scienciam condecorantes, irradiationum enim et aspectum stellarum...perspective sunt....Huius igtur sciencie processus omnium aliarum modis certior est."
} 
with an inventory of previous practitioners, which would prove the utility of the discipline and its respectability by way of those previous authorities (Boudet 1994, 10-11). Simon the Phares's Élucidaire, which became the Recueil des plus célebres astrologues, was still in the making when Ciruelo's Sphera went to print. Ciruelo used Josephus's (37-ca. 100) Antiquities to mention the tradition that attributed knowledge of astrology to Noah and Abraham, proceeding then to Hermes and Ptolemy, then medieval authors, citing among others Tebit (Thābit ibn Qurra, 826-901) and Alfarganus (Ahmad ibn Muhammad ibn Kathir al-Farghani, ca. 805-870) before getting to Sacrobosco himself and king Alphonse X of Castile, followed by Pierre d'Ailly, whom he couldn't fail to cite, and ending with the two most relevant scholars of fifteenth century astronomy, Peuerbach (1426-1461) and Regiomontanus (1536-1476). ${ }^{43}$ "Enjoy the regal and imperial astrology, which is commended by the piety, dignity and sublimity of its authors," Ciruelo concluded. ${ }^{44}$

His last argument appealed to the kind of piety he had just mentioned in association with those authors. Astrology was a discipline which aimed at raising men to the knowledge of the work of God, he said. ${ }^{45}$ Establishing the general notion of nature as a divine epiphany allowed for a justification of the sciences in general, and in this case of astrology in particular, as it fit coherently into such a view of nature. This was one of the most important ways to defend astrology when it was confronted with the principles of Christianity. It was obviously necessary to hold up astrology's pietas, meaning both its morality and its respect for divinity (Ernst 1991a, 251-53, 1991b). This argument was connected in the preface to the one insisting on the utility of astrological predictions, which was also a traditional defense of astrological knowledge.

Ciruelo had constructed a solid defense of astrology in this preface to the Sphaera, with some of the same arguments that would be repeatedly used by astrologers of the sixteenth and seventeenth centuries. His intention was not, however, to turn Sacrobosco's treatise into an introduction to astrology. The work was an introduction to astronomy, and, unlike Cecco d'Ascoli (1257-1327) and Robertus Anglicus (active ca. 1326), Ciruelo did not add the basics of astrology to his commentary. ${ }^{46}$ There was Alcabitius for that (Abu al-Saqr Abd al-Aziz al-Qabisi, active ca. 950), namely his Introduction to the Art of Judgments of the Stars. In deciding to place Pierre d'Ailly's questions on the Sphaera after the chapters to which they applied, Ciruelo gave himself the chance to introduce some astrological content, such as a piece on the nature of the planets and their influences on men (Chapter one of the Sphaera, Questio quinta by d'Ailly). But Ciruelo's aim when choosing to include d'Ailly's ideas could also be related to the defense of astrology as a discipline. D'Ailly's writings demonstrated a fundamental interplay and essential

\footnotetext{
${ }^{43}$ On the literary sources of the Sphaera, see (Martins 2003).

${ }^{44}$ (Ciruelo 1498, a5r): "Gaudeat igitur regia et imperialis astrologia que tanta inventorum auctorumque suorum santitate, maiestate et sublimitate commendatur."

${ }^{45}$ (Ciruelo 1498, a5r): "Finis quoque huius sciencie pius strenuus et divinus est per creaturas scilicet sensibiles ad dei cognitionem homines elevare."

${ }^{46}$ On Cecco d'Ascoli's and Robertus Anglicus's commentaries, see (Thorndike 1949, 48-54).
} 
harmony between his astrological and his theological beliefs (Smoller 1994, 22). His work Concordantia astronomie cum theologia (1414), which had been printed by Erhard Ratdolt (1442-1528) only a few years before in 1490, was one of the main references when authors attempted to resolve possible conflicts between the practice of astrology and the Christian religion (Smoller 1994, 122-30). The constant presence of d'Ailly's ideas in the commentary could be taken as a subtle reminder of the "concordance" of astrology and theology. Inserting d'Ailly's questions into the core of the text gave Ciruelo the chance to insist, after his first gloss on Sacrobosco, on the initial subject he had introduced in the preface, the place of astrology among the mathematical sciences (Chapter one, Questio prima).

The last part of the preface contained not only further arguments in defense of astrology, but specifically those which were needed due to what happened in Paris in 1494. While Ciruelo was there teaching the mathematical disciplines and studying theology, he witnessed the condemnation of astrological prognostications of a judicial nature by the University of Paris in 1494. The theology faculty was acting against the activity of Simon de Phares, condemning his astrological activities and part of his astrological library (Boudet 1994, 1999; Thorndike 1934, 544-61).

Simon de Phares was an astrologer who also claimed to be a physician. ${ }^{47} \mathrm{He}$ had established an astrological practice in Lyon, where he consulted clients and seems to have mainly exercised the branch of astrology known as interrogations. After a royal visit in 1490 and the subsequent fame, he was accused of using a "familiar demon" for his divinatory practice and arrested. This charge was later cancelled, but he was ordered to stop his practice of astrology, and his library was confiscated. He appealed to the Parliament of Paris in 1491. The Parliament asked the faculty of theology at the University of Paris to examine de Phares's library, at least his works on astrology. In 1494, the theologians of the university censored the content of eleven of his astrological works and published a notice condemning judicial astrology. This document was quite a wide condemnation of the discipline, or more specifically of nativities, interrogations, and elections. Knowledge of all the secrets of the future, said the Parisian theologians, as the Papal Bull of 1586 would say a century later, was reserved to God ${ }^{48}$ The theologians were actually focusing on the condemnation of interrogations and elections, and in that, Ciruelo agreed with them. He pointed out the same idea, that those two branches of astrology were to be forbidden, both in the commentary to Sacrobosco and in the Apotelesmata. However, despite how radical the notice of the faculty of theology seemed to early modern

\footnotetext{
${ }^{47}$ Boudet pointed out that there is no evidence of Phares receiving a medical education. For all the details on Simon de Phares's biography, activity, arrest, and condemnation, and for a transcription of the sources related to them, see (Boudet 1988, 1994, 1999). The document of the Parliament was published by (Plessis d'Argentré 1724, I: 324-30).

${ }^{48}$ (Plessis d'Argentré 1724, 325): “...eam nos mathematicam artem seu astrologiam divinatoriam appellamus, quae ex horarum natalium consideratione futuros hominum mores et qua item ex quarumcumque rerum vel operationum horis initialibus futuros eorum successus et casus, fortunas determinative et particulariter praedicere quae etiam cuiusvis interrogationis hora notata et veritatem respondere et omne prorsus cum praesens, tum praeteritum ac futurum secretum revelare ac manifestare se posse, quod divinitas proprium est."
} 
Europeans in 1494, it specified that it was not condemning "true astronomy," which besides the movements of the celestial bodies "conjectured about some of their natural effects." 49 Again, Ciruelo agreed that there was a part of astrology which studied natural influences, and that it was a licit and true liberal art- this he established at length in the preface to Sacrobosco. He did not seem to agree completely with the wide prohibition the document implied, as he defended certain predictions using genethlialogy in his later work, as well as revolutions. Jean-Patrice Boudet explained that the trial of Simon de Phares developed in a repressive context in which any deviation from orthodox faith was addressed with severity, and that divination, including astrology, was associated with blasphemy, as can be seen in royal orders published during the period (Boudet 1999, 108-10). The University-and following its instructions, the Parliament — of Paris prohibited divinatory astrology (astrologia divinatoria), but Ciruelo thought that it was necessary to discuss which aspects of astrology were divinatory and which were natural. And those were the issues he addressed in the preface to Sacrobosco, after he made clear that not all astrology was to be considered judicial or divinatory, and that it was a valid, licit, and worthy discipline.

Pedro Ciruelo's main work in defense of astrology, Apotelesmata astrologiae Christianae, was not published until much later, in 1521, while he was back in Spain as professor of Thomistic philosophy in the very nominalist environment of the University of Alcalá de Henares. Thorndike assumed that Ciruelo published his work in defense of astrology after he had returned to Spain because he then felt on safer ground, due to the theological opposition found in Paris during the last years of the fifteenth century. ${ }^{50}$ This idea is not consistent with the analysis of Ciruelo's strong defense of the discipline in the preface of his commentary to the Sphaera given above. Actually, I argue, it was precisely because of the situation in Paris that he decided to defend astrology so vehemently in his preface to Sacrobosco. He was not hiding his opinion on astrology, as his defense was very explicit, nor did he pretend that his words were unrelated to the condemnation of astrology resulting from the De Phares affair. He was addressing the problems created for the discipline because of the decision of the University of Paris about that case. He stated it both in the same preface and later again in the Apotelesmata. He explained that the same discipline he was praising had been the object of a recent decision by the theology faculty. The watchers of the Catholic truth wanted to keep all disciplines clean of falsity, so they had to condemn "certain writers, liars and corruptors of truth, who

\footnotetext{
${ }^{49}$ (Plessis d'Argentré 1724, 325): "Ne quis autem veram astronomiam, quae corporum coelestium magnitudinem, oppositiones, motusque considerat, quae Solis et lunae aliorumque planetarum conjunctiones vel oppositiones caeteras vel habitudines praedicit, quae item effectus quosdam eorum naturales probabiliter ac prudener in universali conjiciit, quam ut liberalem, nobilem, utilemque artem veneramur." On the distinction in this case, see (North 2009, 292).

${ }^{50}$ Thorndike expressed this theory as follows: "Whether Ciruelo expressed such favorable views towards astrology during his residence at Paris before 1502 may be doubted. At any rate he did not print them until 1521 in Spain, and one suspects that he felt somewhat freer to express himself on the subject there and surer of a sympathetic audience." (Thorndike 1941, 275-79).
} 
had tried to mix the chaste astrology with courtesan sciences." 51 This was one of the main defenses on which astrologers relied: it was the specific practitioner who mixed false ideas and superstitions with his astrology who had to be condemned. Ciruelo made a point of this in the preface when making the reference to the condemnation of Paris of 1494. In the Epistola proemialis of the Apotelesmata, Ciruelo mentioned again the situation in Paris as he introduced his discussion on who was entitled to decide about the nature of astrology and its legitimacy, and on the training of theologians and their lack of knowledge of astrology. ${ }^{52}$

Further evidence that the notice condemning the books and practices of Simon de Phares in Paris in 1494 had a role in the way Ciruelo defended astrology in the preface of his commentary to Sacrobosco's Sphaera is the new version of it he prepared for the 1526 edition (Fig. 3.3). The prohemium to this edition was a shortened version of the original one. In it, Ciruelo praised Lefèvre d'Étaples and mentioned his experience in Paris making his living as professor of mathematics. ${ }^{53} \mathrm{He}$ explained that he wanted to make the new version easier to read for the students of the University of Alcalá, and to eliminate his mistakes and youthful verbosity (Fig. 3.4).$^{54}$ The context had changed completely in terms of his own status and that of astrology as a discipline. He would not have worried about the 1494 decision against Simon de Phares anymore, because it was by then a past event without much effect. After the publication of Pico della Mirandola's (1463-1494) work against astrology, hardly anything else would have rivaled its importance. In the decade of the 1520s, Ciruelo addressed this issue with the Apotelesmata and the Reprobación. The preface to Ciruelo's commentary to the Sphaera of 1526 did not mention De Phares. However, Ciruelo had not abandoned his objective of placing a defense of

\footnotetext{
${ }^{51}$ (Ciruelo 1498, a5r): "Nec tamen qui divinam astrologiam tot tantisque laudibus efferre conor determinationi cuidam alme facultatis theologie doctorum parisiensium super quibusdam mathematicis libris nuper edite inficior....Ideo predicti doctores et veritatis catholice zelatores volentes tam dominam quam eius ancillas omni falsitate purgatas inmunesque custodire: falsarios quosdam scriptores et veritatis corruptores (qui castissimam astrologiam cum scienciis meretriculis nixi sunt collocare eamque apud dominam suam de magno superstitionis crimine falsa quedam immiscentes diffamare tentarum) a generosissima astrologorum schola perpetuo eiiciendos et dampnandos iamque dampnatos pronunciarunt."

${ }^{52}$ (Ciruelo 1521, a2v): "Verum de iudiciis astrologicis tunc temporis nihil egimus Parisii, eo quod vulgaribus theologis essent invisa atque ludibrio exposita. Nam tota eorum facultas plures iudiciorum astronomicorum libros anno Christi domini 1494 examinans, quesdam illorum manifeste erroneos infide et moribus alios valde suspectos aut dubios damnavit." On Ciruelo presenting himself as the perfect judge for what was orthodox in astrology, see (Lanuza 2017, 9-14).

${ }^{53}$ (Ciruelo 1526, a2v): "Cum in adolescentia mea Parisiensium theologorum scholas famigeratissimas perlustrarem, atque ex professione matheseos mihi necessaria ad victum et indumenta compararem, accidit tunc Iacobum Stapulensem praeclarum certe nostra tempestate philosophum, egregium quendam edere in opusculum sphaericum Ioannis de Sacro Busto commentarium et mox ipsum excussoribus imprimendum trader."

${ }^{54}$ (Ciruelo 1526, a2v): “...hanc sphaericam meam elucubrationem revidere, corrigere, emmendare breviorem facere, atque in melius permutare, eliminata prorsus ab ea. omni prolixitate, omni barbarie omnique iuvenili loquacitate, sicque renovatam eisdem complutensibus calcographis et quidem artificiosissimis formanda tradere, ad usum nostrorum adolescentum hic et alibi philosophantium.”
} 


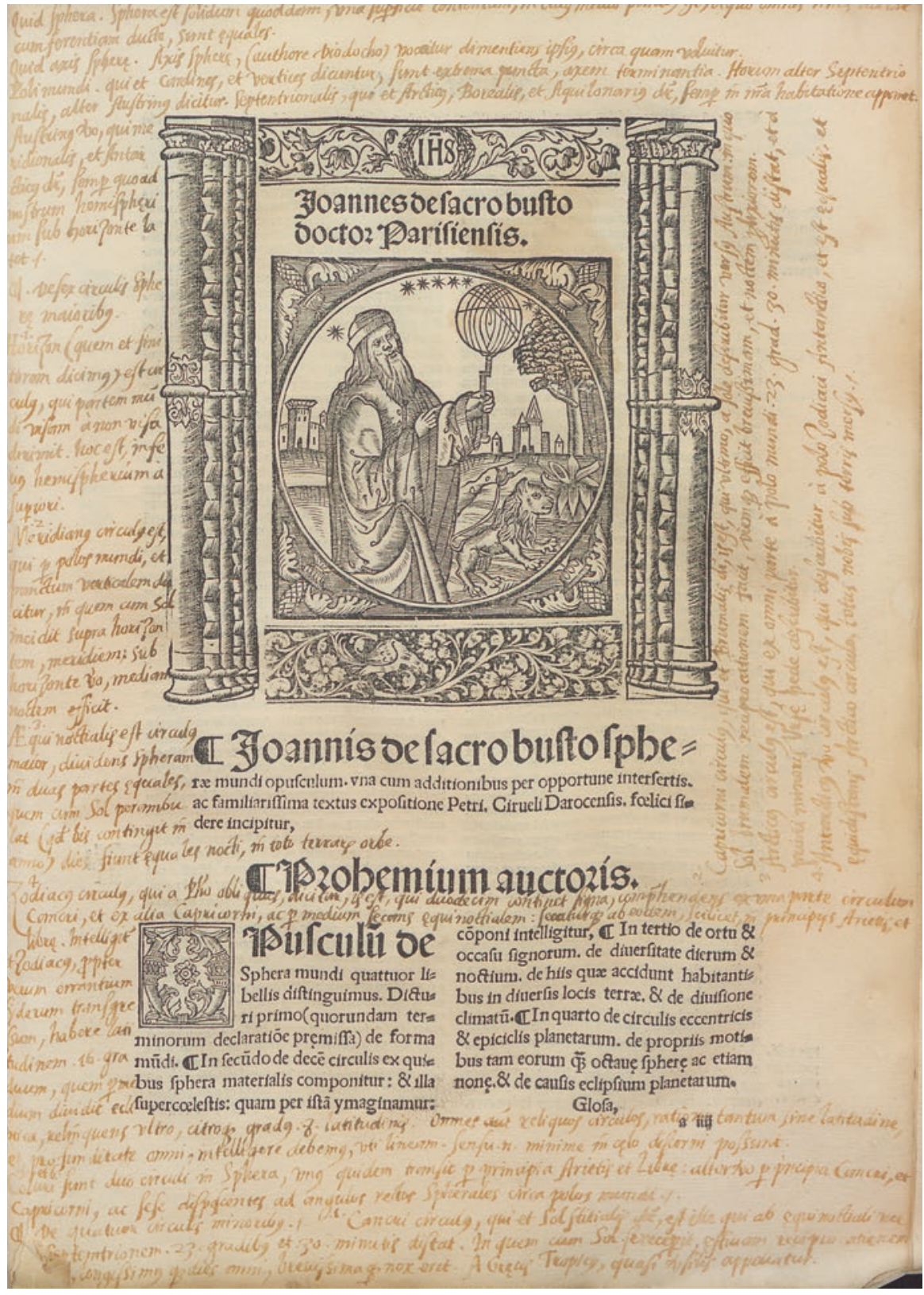

Fig. 3.3 Cover page. This copy at Seville is one of the many with marginal notes denoting the intense use of this commentary of Sacrobosco's Sphere. From (Ciruelo 1526). Courtesy of the Biblioteca Universidad de Sevilla 


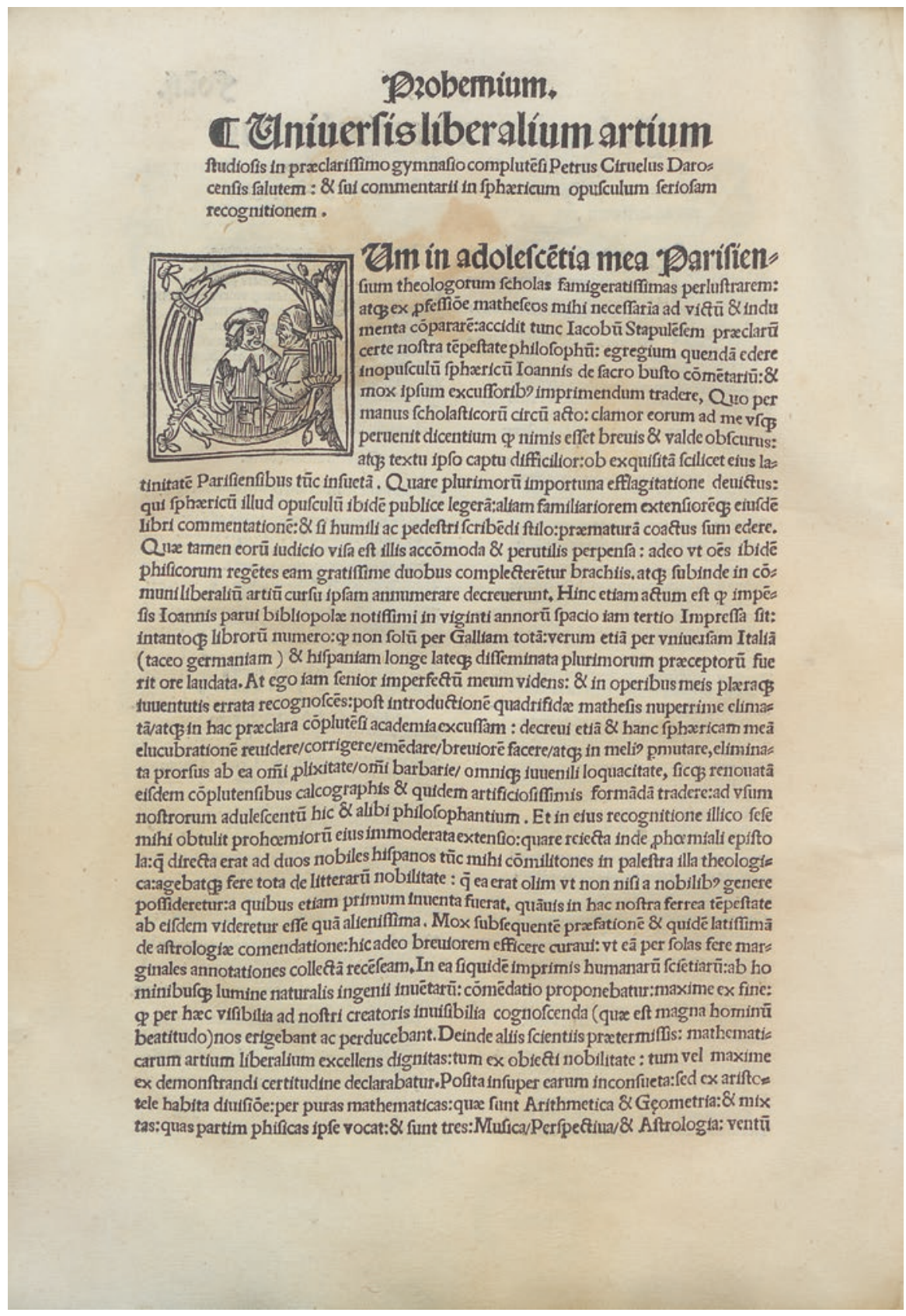

Fig. 3.4 Preface. This first page of the 1526 edition can be compared to Fig. 3.2. It contains the same initial arguments and praise of mathematics, discussing the dignity of mathematical sciences, in a briefer and more concise structure. From (Ciruelo 1526). Courtesy of the Biblioteca Universidad de Sevilla 
astrology in his commentary. He did it by including the same arguments he had put in the original, only in a shortened version. Some of them were reduced to a single sentence: the nobility of mathematical disciplines, the division between pure and mixed disciplines, the higher status of astrology due to its object and its mixed physico-mathematical nature. The genealogy of the discipline was only slightly abridged. The last part maintained that the science of the stars had two parts, one focusing on the movements of celestial bodies, the other on their (strictly natural) effects. ${ }^{55} \mathrm{He}$ did not leave out citing the Almagest and the Quadripartitum together. He finished this new version by insisting on the excellence of astrology, and on the utility of the Tractatus de sphaera of Sacrobosco to learn basic astronomical knowledge. The shortened preface of 1526 , less prolix indeed, seems to transmit less urgency, which is consistent with its publication in a dissimilar context.

When Pedro Ciruelo published the Apotelesmata astrologiae Christianae, it was due to a different situation. He felt the need to answer Pico della Mirandola's Disputationes adversus astrologiam divinatricem and his attack on astrology. When he printed the commentary to the Sphaera he already knew some of Pico's works. He referred to him as a man who had arrived at the top of all human and divine sciences, and who shone as a new star. "What he ignores, nobody knows," said Ciruelo about Pico. ${ }^{56}$ But when he made a first defense of the discipline in the Sphaera, it does not seem to have been due to the Disputationes, although they had been published already in 1496. He did it because of the condemnation of Simon de Phares.

The differences between the kind of defense that Ciruelo created in these two works (the commentary and the Apotelesmata) are due to the context of the moment and the kind of attack against astrology to which he was responding. But the commentary to the Sphaera, with its solid combination of arguments defending astrology by associating it with mathematics, and the Apotelesmata, where the aim was to answer Pico's work while renovating astrology, constitute a unity in which the first one functions like an introduction to the second. In the Apotelesmata, the same simple arguments are mentioned-developed in different ways, but not literally repeated.

\footnotetext{
${ }^{55}$ (Ciruelo 1526, a3r): “...pars theorica seu contemplativa de magnitudinibus, mensuris, numeris et motibus coelorum et stellarum.... Altera vero est quasi practica, quia iudiativa effectuum naturalium ex actione corporum coelestium in terra et mari in hominibus et brutibus animalibus atque in terrae vegetabilibus contingentium, voacturque ab eodem proprie astrologia."

${ }^{56}$ (Ciruelo 1498, a3r): “...qui....et virtutes et scientias licito amore prosequuntur unde et Johannes Picus italorum principum gloria nitidissimumque ornamentum diebus hiis velut novum sidus emicuit. Qui omnium tam humanarum quam divinarum scientiarum fastigium adeo celeriter optinuit ut omne genus scibile antequam adolescentiam excederet calluerit et quod is ignoraverit sapiat nemo."
} 


\section{The Structure of the Apotelesmata and the Renovation of Astrology}

Between the first printing of the Disputationes in Bologna in 1496 and the publication of the response to it by the Pedro Sánchez Ciruelo in 1521, several other answers to Pico della Mirandola's work had been already published, mainly in Italy. Before Ciruelo wrote his Apotelesmata astrologiae Christianae, Lucio Bellanti (died ca. 1499) had already printed his Defensio astrologiae twice (in 1498 and 1502) and Giovanni Pontano (1426-1503) had published his answer in De rebus coelestibus in 1512 (Bellanti, 1498; Pontano, 1512). Agostino Nifo (ca. 1473-ca. 1540) had printed his commentary on the Tetrabiblos in 1513, and according to the studies of Paola Zambelli, Tiberio Russiliano (1490-ca. 1570) had also mentioned his intention to "destroy the disputations" around 1519 (Zambelli 1986, 1994; Nifo 1513).

The Apotelesmata was in a certain way a combination of Bellanti's choice to respond to Pico's work with that of Pontano-if we see Bellanti as a model in which each and every argument in the Disputationes is summed up and responded to in the same order-and Pontano's De rebus coelestibus, written with the objective of answering Pico by constructing a complete treatise on astrology. In his work, Ciruelo did both.

When he decided to structure his work in four books after Ptolemy's Tetrabiblos, it was an exercise inspired by Renaissance imitatio and by the general principle of going back to the authority of antiquity for the renovatio of the discipline. In the context of the debates about astrology in sixteenth century Europe, this meant a clear position, that of those who based their defense of astrology on the idea that the valid discipline, "pristine" as it was contained in Ptolemy's work, had been corrupted by later medieval - particularly Arab - additions, from which it had to be cleaned to restore a "truer" astrology. Ciruelo was one of the scholars with an interest in astrology who proposed such a view. The condemnation in Paris and Pico's work made him aware of the need for a renovation of the discipline. At that time, other scholars were also defending a return to Ptolemaic astrology. In this respect Ciruelo was not different from Pontano, from Nifo, from Albert Pigghe (1490-1542), and others, before Girolamo Cardano (1501-1576) famously advocated for such a way to recreate the discipline in his commentary to the Tetrabiblos in $1547 .{ }^{57}$ The argument of the "return to Ptolemy" was also to be found in Melanchton (Pantin 1987). Cardano's role in this debate was crucial during the second half of the sixteenth century. His commentary on Ptolemy's astrological work is the best-known example of the larger theme-found in many authors of the period-of the need to reform astrology by a systematic program of study. Ciruelo would have concurred with this idea. Cardano's opinion, like Ciruelo's, was that the best way to reestablish his art was through the study of Ptolemy (Grafton 1999, 134). He claimed that he

\footnotetext{
${ }^{57}$ On Bellanti and Pontano, see (Faracovi 2008a, b, a, b; Akopyan 2017). On Pontano, see also (Desantis 1986; Rinaldi 2002). On Pigghe, see (Vanden Broecke 2003, 85-99). On Cardano, see (Grafton 1999, 134-53; Ernst 2001). See also (Rabin 1997).
} 
had clarified the validity of astrological principles to be found in Ptolemy's Tetrabiblos, but he also highlighted the limits of the discipline, its imperfection, and he criticized other practitioners in the frame of distinguishing good from bad astrology (Grafton 1999, 91-108, 127-55).

This was one of the ways in which Ciruelo connected the arguments he had introduced in the commentary on the Sphaera with those he developed in the Apotelesmata. He had already stated in the preface to Sacrobosco that Ptolemy's astrology was the "pure" and legitimate one, and that later-medieval-additions had mixed with it false ideas and practices. He particularly cited as erroneous the astrological ideas of Albumasar (Abū Ma'shar Ja'far ibn Muḥammad ibn 'Umar al-Balkhī, 787-886), Abenragel (Abū l-Ḥasan 'Alī ibn Abī l-Rijāl, active late tenthearly eleventh century), and Guido Bonatti (1210-1296). To reform astrology, it was necessary to return to Ptolemaic astrology, creating a new discipline by eliminating certain theories from the intervening period..$^{58}$ What had constituted a few paragraphs in the prefaces to the Sphaera became the basis for Ciruelo's main work in defense of astrology. The idea of the renovation of astrology was often structured upon the distinction between a true and a false astrology. The first would be learned and legitimate; the second would be superstitious and incompatible with Christian doctrine (Walker 1958; Ernst 2001, 39-68). Medieval authors had already attempted to establish criteria to guide the efforts to distinguish between natural and judicial astrology. Natural astrology would interpret the effects that the properties and movements of celestial bodies caused naturally on earthly bodies and events, neither requiring supernatural intervention nor denying human free will. Judicial astrology predicted human activities which depended on the decisions of men, but its deterministic interpretation presupposed the annulment of free will, of the possibility of unpredictable events, and of divine intervention. These theoretical descriptions of the two kinds of astrology were the subject of many works during the early modern period. They insisted on the existence of a good astrology which was true and licit from the point of view of the Church, and a false, superstitious, illicit one. But opinions on which theories and practices must be classified as one or the other were varied and contradictory. Medieval antecedents were to be found in the works of Roger Bacon and Albertus Magnus (Crombie and North 1970, 377-85; Molland 1997, 68-71, Zambelli 1986, 1992). Ciruelo discussed the issue in the Apotelesmata for a learned audience, and later, in his Reprobacion de supersticiones y hechicerias (Reprobation of superstitions and sorceries), first published in 1537, he tried to explain the difference between the two kinds of astrology in the vernacular to reach a wider audience. True astrology, he explained, was based on the natural effects of the stars on air and water, thus affecting the weather and human health, complexions, and inclinations. False astrology predicted things related to human free will

\footnotetext{
${ }^{58}$ (Ciruelo 1498, a5v-a6r): "Hanc tamen astrologiam multi ut dictum est plura falsa immiscentes late ampliarunt, nam Albumazar, Hali Abenragel, Guydo Bonati, Abraham Avenezre et multi alii...."
} 
and chance. ${ }^{59}$ While brief in form, this was an argument that had also been present in Ciruelo's commentary on Sacrobosco. When discussing the contents of the third chapter on the risings and settings of the signs, and on climates and the habitability of the diverse zones of the earth, he repeated the differences among the mathematical disciplines explained in the preface. He then explained that several of them were "artes mathematice prohibite ab ecclesia que sunt divinatorie" (Ciruelo 1498, h4v). The list of the prohibited arts is reminiscent of those he criticized in the Reprobación. His efforts to establish a distinction between licit and illicit astrology, and to distinguish the former from any divinatory art, was quite constant throughout his career. He was successful in spreading these distinctions. The three reprints of the Sphaera and the Apotelesmata were received only by scholarly audiences, but his vernacular Reprobación, containing the same distinction, had a huge impact. It was printed at least ten times during the sixteenth century since its first edition in 1537 (Mateo Ripoll 2002). ${ }^{60} \mathrm{He}$ was repeatedly cited as an authority on the subject during the seventeenth century debates on astrology at the core of the Inquisition (Lanuza Navarro 2017).

The determination of which astrological doctrines had to be considered unacceptable from the point of view of Catholic orthodoxy was associated in the Apotelesmata with the explanation of all aspects that constituted a 'true' Ptolemaic astrology. Both were directly linked, which was also the reason why Ciruelo presented himself as a perfect judge for astrological issues. His knowledge of astrology, which other theologians lacked, was the reason he considered himself better qualified (Lanuza Navarro 2017).

Ciruelo devoted a great portion of the Apotelesmata to forming an answer to each and every argument contained in Pico's attack. ${ }^{61}$ His response to the Disputationes was organized in two parts. The first part responded to Pico's books I and II, and was placed before the astrological treatise. Then Ciruelo's work became a manual

\footnotetext{
${ }^{59}$ (Ciruelo 1551, 16r-17r): "La verdadera astrología habla de cosas que se causan por las virtudes de los cielos, que con sus movimientos y luces alteran el ayre y la mar, y la tierra, y assí causan diversos effetos de tiempos..., y porque los cielos y las estrellas alterando el ayre y la tierra también alteran a los hombres..., assí los cielos causan a nuestros cuerpos diversas calidades, complexiones, passiones y enfermedades, diversas inclinaciones y abilidades.... Y en estos juicios no hay vanidad ni superstición alguna, porque aplica a los effectos sus causas que tienen virtud natural para los hazer..., y esta astrología es lícita y verdadera sciencia como filosofía natural, o la medicina.... La falsa astrología no es arte ni sciencia verdadera, antes es una superstición, porque de los cielos y estrellas presumen de juzgar de cosas que ellas no pueden ser causas dellas..., las cosas de acaescimientos por diversos casos de fortuna...y los secretos del coraçón y voluntad del hombre... [que es] libre."

${ }^{60}$ On the Reprobación, see (Ebersole 1962; Zamora Calvo 2008; Tausiet Carles 1992).

${ }^{61}$ (Ciruelo 1521, a4r): "In secundo prologo ponuntur argumenta et responsiones circa primos duos libros operis Mirandulani Contra astrólogos;" (Ciruelo 1521, C4r): "Restat etiam pro nostri operis complemento ad argumenta que contra veritates astrologicas fieri consueverunt respondere. Et que nobilis quidam Joannes Picus Mirandula insignis orator et sumus in arte dicendi, putavit se recollegisse omnia argumenta que contra haec facultatem apparentiam aliquam habent in suo opere dicto contra astrologos...."
} 
explaining astrological theories, followed by his glosses on the pseudo-Ptolemaic Centiloquium. At the end of the work he placed the second part of his answer to Pico. In this, he responded more briefly to the rest of the books (III to XII) of the Disputationes.

The internal structure of the texts of these 'Responsiones' is, like Bellanti's work, that of the scholastic tradition. Ciruelo summed up the content of each of the chapters of the Disputationes, following its order, and then answered Pico's arguments with his own opinions.

The arguments with which he rebuked Pico's criticisms in the second book were not innovative, which is unsurprising as Pico also drew his attacks from the critical tradition. The re-elaboration of medieval and classical arguments which were previously pointed out in the Disputationes happens thus in both the condemnation and the responses, sometimes lending a kind of circularity to the two in tandem, as Pico had considered in advance the usual answers of astrologers to his objections and created his work by responding to them preemptively. ${ }^{62}$

Claims for and against astrology had classical origins and passed through medieval recreations. According to Bouché-Leclerc, after the first attacks had been issued, nothing new followed; they had already presented every argument and the ensuing criticisms only repeated themselves without innovations (Bouché-Leclercq 1899, 571). This is not as straightforward as he claims. Even if the participants in the early modern polemics against astrology made use of the same arguments, this does not mean they were mere repetitions. In the first place, Pico's Disputationes is much more than a list of the same arguments, and, as put by Cesare Vasoli, it is not a work reducible to the traditional argumentations of the anti-astrological polemics of an Augustinian nature and origin. ${ }^{63}$ In the second place, more generally, even if the arguments are the same, the context—socially speaking, politically speaking, scholarly speaking - was seriously different in each moment, and that altered not just the way they were presented, but probably also their meaning. ${ }^{64}$ It would be wise to follow the arguments through time and see how they were reproduced in different contexts to understand how they changed and the roles they played at different points in this long-lasting debate.

\section{Conclusion}

Pedro Sánchez Ciruelo was a scholar of scholastic training, educated in the nominalist tradition. He has repeatedly been described as a humanist (Flórez et al. 1990, 50-53; Albares 1996). It is difficult to agree with applying such a label to him, due as much to the nature of his writings and activities as to the problematic definition

\footnotetext{
${ }^{62}$ On the re-elaboration of arguments, see (Caroti 2008, 72-78).

${ }^{63}$ Arguments which according to Boll and Bouché-Leclercq were traceable to Carneades through Cicero (Bouché-Leclercq 1899, 571, citing Boll 1894, 182). See, against that idea, (Vasoli 2008, $5)$.

${ }^{64}$ On the difference that social and political context made in arguments concerning astrology, see (Vanden Broecke 2016).
} 
of the term "humanism." Created as a historian's category in the nineteenth century after the Renaissance term "humanist," humanism has been the subject of much controversy and of varied and often contradictory views. Even after leaving behind nineteenth and twentieth century debates over the meaning of humanism and over its main traits, scholars currently working on several aspects of Renaissance culture and society still disagree about how best to categorize it. ${ }^{65}$ Assuming certain points of agreement, I will try to briefly expose why applying them to Ciruelo's works is problematic. Some characteristics described as typical of humanism can be found in his writings; however, the weight of medieval scholasticism in them cannot be denied either.

According to the traditional definition of humanism, humanists promoted the disciplines concerning language-grammar, rhetoric, and poetics-the studia humanitatis, as opposed to the predominant scholastic Aristotelian philosophy. One of the points of discussion about it is, of course, to what extent it really opposed scholastic philosophy, as the borders between them cannot be taken as so neat and clear as the historical actors, and many historians, affirmed. ${ }^{66}$ The not-sostraightforward definition of what medieval Scholasticism was has been another point of discussion, as well as the role of many medieval legacies in humanist attitudes (Fubini 2006). It is reasonable to agree with Paul Oskar Kristeller that reducing fifteenth century culture to a confrontation between these two cultural movements is a misrepresentation of it, that the culture of this period was more varied, and that humanism and Scholasticism coexisted during the fifteenth and sixteenth centuries (Mazzoco 2006a, 17). Seeing Ciruelo's life and works in a context of coexistence seems quite reasonable as well. If his writings can be said to share some of the traits of humanist works, it is also certain that he cultivated literary genres usually associated with scholastic activity. He wrote commentaries on Aristotle's Posteriora analytica, he used pedagogical dialogues, disputations, and disputations in the form of quaestio ${ }^{67}$ His dedication to logic and his role as the professor of Thomistic theology for three decades can hardly be ignored either. ${ }^{68}$

The values of the humanists pervaded scholarship as a whole, including scholastic commentaries of the sixteenth century (Dear 2001, 32). Humanists put emphasis on the value of education to create better citizens, on the relevance of discarding medieval Latin in favor of classical Latin because they saw it as inseparably related to the wisdom of the content, and on the idea of a rebirth of classical culture,

\footnotetext{
${ }^{65}$ For a summary of the nineteenth and twentieth century debates over humanism, and the relevant roles played by different scholars, including the significant works of Burckhardt and Haskins, and of Baron, Garin, and Kristeller, see (Mazzoco 2006a). For several current views of humanism and the most relevant aspects of it, some of them contradictory, see the varied essays in this edited volume. See also (Grendler 2002; Fubini 2001, 25-27; Celenza 2004, 16-57).

${ }^{66}$ Kristeller insisted that humanism evolved out of the grammatical and rhetorical medieval traditions. Discussion on the real meaning of Kristeller's thesis and influence, in (Mazzoco 2006b, 176-77).

${ }^{67}$ See an analysis of the Dialogue at the end of the Sphaera, and of the genres in the works of Ciruelo, in (Gómez Sierra 1999, 2000).

${ }^{68}$ On Ciruelo’s logic, see (Ayala 1993; Muñoz Delgado 1964, 1966, 1967).
} 
of renewing culture by a return to the language and knowledge of antiquity, which in their opinion were linked. Language or the recovery of ancient texts for better translations seems not to have been one of Ciruelo's concerns, at least not concerning scientific works. He did, however, embark on a translation from Hebrew of parts of the Old Testament, though late in his life. This must be analyzed in the context of another debate concerning humanism, this one from the point of view of religious studies and focused specifically on Spain. Marcel Bataillon's immeasurably influential Erasme et l'Espagne defended the idea that humanism in Spain arose exclusively from the supporters of Erasmus and his doctrines, spiritual ideals, and philological criticism (Bataillon 1966) ${ }^{69}$ Bataillon presented Ciruelo as the epitome of conventional Catholicism and an enemy of Erasmus, and therefore as the absolute opposite of a humanist. ${ }^{70}$ Lou Ann Homza demonstrated how biased this view of humanism, and of this scholar, was, by analyzing Ciruelo's theology and his religious works. She concluded that although Ciruelo's early works displayed no respect for the integrity of the text or interest in exegetical issues, he evolved, became a Hebrew scholar and showed philological interests, embraced the humanist historicist approach and developed a new exegetical awareness (Homza 1992, 60-101, 175-209). His "altered approach to biblical hermeneutics qualifies him as a Renaissance humanist" (Homza 1992, 11, 284).

From the point of view of the historian of science there is also a long debate on the relationship of humanism and science to be taken into account. Scholarship discarded long ago the traditional view of an opposition between Renaissance humanism and scientific thought, once defended by Thorndike (Blair and Grafton 1992, 535). In the last decades, several scholars have made a 'reassessment' of humanism and its interaction with science, pointing out, among other issues, the impact of ancient texts of a scientific nature made available by humanist scholarship and the press, and the spread of scientific ideas through humanist works (Blair and Grafton 1992; Grafton 1991).

Regiomontanus has been held up as an example of a humanist specialist in Latin literature who was simultaneously a mathematician and astronomer-an example of how the ideal of renewing culture by a return to antiquity was applied to the mathematical sciences. In Peter Dear's words, he transferred the language of the humanists regarding decline and renewal to the specific arena of mathematics, and his humanist rhetoric of 'restoration' in the Epitome found a receptive audience (Dear 2001, 33-34). It is not difficult to relate Regiomontanus's defense of mathematics as well as his regard of astronomy as the highest of the mathematical sciences to Ciruelo's words in the preface to Sacrobosco. Ciruelo's insistence on returning to Ptolemaic astrology could be read as participation in the humanist revival of ancient sources and practices. In this he would be following Regiomontanus's, as well as

\footnotetext{
${ }^{69}$ For a description of the scholarship concerning humanism in Spain as presented by Bataillon, and a criticism of what it erroneously entailed, see (Homza 1992).

${ }^{70} \mathrm{~A}$ transcription of Ciruelo's opinions on Erasmus in the Assembly of Valladolid in 1527, can be found in (Beltran de Heredia 1972, 50-53). See an analysis of it in (Homza 1992, 209-81, 1997, 2000, 49-76).
} 
Lefèvre d'Étaples's, humanist way of addressing the issue. The same could be said about basing his argument for the value and nobility of astrology on an appeal to ancient authorities: the strategy of creating a genealogy of a discipline that extends as far back into antiquity as possible and ties in the most famous individuals to legitimize it and justify its practice was also a humanist move (Grafton 1992). In this sense, it must be pointed out that in the dialogue at the end of the commentary Ciruelo also discusses the function of authoritas. The use of historical narrative to work through problems of the legitimacy and nature of disciplines, as used by Regiomontanus and others, has been termed "the most humanist of activities" (Goulding 2006; Popper 2006). Still, one should not lose sight of how Ciruelo, like Lefèvre d'Étaples, also built his defense on Boethius's claims for the value of mathematics, and that this medieval tradition dovetailed with the humanist interest in mathematics (Moyer 2014). Nor should one lose sight of the fact that as much as a mathematician and astrologer, Ciruelo wrote as a theologian, and that his main concern was to establish the parts of astrology acceptable from the point of view of orthodox Catholic doctrine.

Ciruelo's preface is strikingly similar to Regiomontanus's inaugural oration on the history and utility of the mathematical arts at the University of Padua in $1464 .^{71}$ The main features were shared: praise of the mathematical arts and its practitioners, a history of mathematics, the utility of the discipline and its supremacy based on certainty, and among the mathematical sciences, the superiority of astrology because of the knowledge it provided of the secrets of God. Another idea used by Ciruelo in the commentary on Sacrobosco, that astrology encompassed all other branches of mathematics (arithmetic, geometry, etc.), could also be found in the letter contained in some copies of Regiomontanus' Epitome, as Robert Westman has recently pointed out. This letter, written by Giovanni Battista Abiosi (active in the last decades of the fifteenth century), was also an encomium to astrology (Westman 2016, 17).

Regiomontanus's oratio is considered an example of a humanist rhetorical text on the revival of ancient mathematics. James Byrne has shown, however, that even if it is stylistically consistent with humanist norms, its vision is grounded in the medieval university's mathematical curriculum and does not reject medieval authorities (Byrne 2006). Stylistically speaking, Ciruelo's preface would probably not be considered humanist, as he shares the vision of the scholastic mathematical university training and the respect for medieval authorities.

In this paper I did not intend to place Ciruelo into one or another category or to discuss his humanist versus his scholastic traits. The aim was to analyze his defense of astrology, and to show that we get a richer understanding of Ciruelo's works involved in that defense, by placing them in their own specific context.

In the case of the preface to Sacrobosco, he wrote it while trying to establish his relevance as a professor of the mathematical disciplines, including astrology, in Paris. When Simon de Phares and his astrology of elections and interrogations, two

\footnotetext{
${ }^{71}$ For a study and description of Regiomontanus's oratio at the University of Padua in 1464, see (Byrne 2006).
} 
astrological practices very much in conflict with Christian doctrine, were condemned by the faculty of theology in 1494 in a decree that was critical of all branches of astrology, Ciruelo had to defend the legitimacy and importance of the discipline he was teaching. He placed this defense in his commentary on the Sphaera of Sacrobosco, the traditional work for teaching astronomy, and used the arguments that aimed to praise the virtues of astrology and the mathematical disciplines and to differentiate the "good" from the "bad" astrology. Those were the arguments that would help him vindicate his place at the university and reinforce his status there. Placing the defense in the most widely read of all works on astronomy in academic circles, in a commentary addressed to an audience of students and professors, was a wise strategy. ${ }^{72}$

When he published the Apotelesmata two decades later, in the middle of the debates about the discipline renewed at the end of the fifteenth century by the publication of Pico de la Mirandola's Disputationes, the arguments Ciruelo highlighted were different. He focused then on the creation of a whole corpus of astrological knowledge not in conflict with Christian doctrine. One of his objectives was to set up guidelines that would make himself seem a valid authority in decisions about astrology. To this end, he emphasized his training as a theologian at the University of Paris, one of the reference colleges for theology. This, combined with his knowledge of astrology resulting from his earlier training in mathematics and astrology at the University of Salamanca-knowledge well exposed in the work-would make him the perfect judge.

The works aiming to defend astrology before and after Pico della Mirandola's attack followed different strategies according to the concrete ideas of their authors. They shared many arguments, as is obvious from the overlap between Ciruelo's arguments and Regiomontanus's and Bellanti's, for instance. Those arguments were inherited from the medieval tradition, but their particular context determined what was highlighted in each case and in what way the arguments were presented. The case of Ciruelo shows that his way of presenting the defense was immersed in the specific context in which he was living, and that it grew in part from the perceived need to vindicate his own status and that of the discipline within two different scholar communities at two points in time.

\section{References}

\section{Manuscripts}

Torres, Diego de. Sphaera de Sacrobosco. In Tratados de astronomía. mss/3385, fols. 189r-99v. Biblioteca Nacional de Madrid, Spain.

\footnotetext{
${ }^{72}$ On the diffusion of diverse commentaries to Sacrobosco's Tractatus de Sphaera and the general relevance of it, see (Valleriani 2017; Crowther et al. 2015).
} 


\section{Primary Sources}

Bellanti, Lucio. 1498. Liber de astrologica veritate et In disputationes Ioannis Pici aduersus astrologos responsiones. Florence: Gherardus de Haerlem.

Ciruelo, Pedro. 1495a. Arithmetica speculativa Thome Bravardini bene revisa et correcta a Petro Sánchez Ciruelo Aragonensi mathematicas legente. Paris: Guy Marchand. (reprinted Paris, 1502).

1495b. Geometría speculativa Thome Bravardini. Paris: Jean Petit. (reprinted 1502, 1508, $1511,1530)$.

. 1495c. Tractatus Arithmeticae Practice qui dicitur algorismus. Paris: Guy Marchand. (reprinted 1502, 1505, 1509, 1513, 1514).

- 1498. Uberrimum sphere mundi comentum intersertis etiam questionibus domini Petri de Aliaco. Paris: Jean Petit. http://hdl.handle.net/21.11103/sphaera.100038 and http://hdl.handle. net/21.11103/sphaera.100274.

. 1508. Uberrimum Sphere mundi commentum. Johannis de sacro busto anglici, una cum textualibus optimisque additionibus ac uberrimo commentario Petri Ciruelli; intersertis etiam questionibus domini Petri de Aliaco. Paris: Jean Petit. http://hdl.handle.net/21.11103/ sphaera.100642.

- 1515. Habes lector Iohannis de sacro busto sphere textum una cum additionibus non aspernandis Petri Ciruelli. D. Paris: Jean Petit. http://hdl.handle.net/21.11103/sphaera.100988.

- 1516. Cursus quattuor mathematicarum artium liberalium. Alcalá: Arnaldo Guillén Brocar. This work was reprinted in Alcalá in 1526 and 1528.

- 1519. Prima pars logices ad veriores sensus textus Aristotelis. Alcalá: Arnaldo Guillén Brocar.

1521. Apotelesmata astrologiae Christianae. Alcalá de Henares: Juan de Eguía.

1526. Opusculum de sphera mundi Joannis de sacro busto: cum additionibus: et familiarissimo commentario Petri Ciruelli Darocensis: nunc recenter correctis a suo autore: intersertis etiam egregijs questionibus domini Petri de Aliaco. Alcalá de Henares: Miguel de Eguía. http:// hdl.handle.net/21.11103/sphaera.100884.

- 1528. In Posteriora analytica commentarius. Alcalá: Miguel de Eguía. (two new editions in 1529).

- 1551. Reprobación de supersticiones y hechicerías. Medina del Campo: Guillermo de Millis.

Le Kalendrier des bergers. 1493. Paris: Guy Marchant.

Nifo, Agostino. 1513. Ad Apotelesmata Ptolomaei eruditiones. Naples: P.M. De Richis.

Pontano, Giovanni. 1512. De rebus coelestibus. Naples: Sigismundus Mayr.

Savonarola, Girolamo. 1496. Revelatio de tribulationibus nostrorum temporum. Paris: Guy Marchant.

\section{Secondary Literature}

Akopyan, Ovanes. 2017. Controversies on astrology in Renaissance Italy (late 15th-early 16th centuries). $\mathrm{PhD}$ Thesis. University of Warwick.

Albares Albares, Roberto. 1996. El humanismo científico de Pedro Ciruelo. In La Universidad Complutense Cisneriana. Impulso filosófico, científico y literario, ed. Luis Jiménez Moreno, 177-205. Madrid: Editorial Complutense.

Albertson, David. 2014. Mathematical theologies: Nicholas of Cusa and the legacy of Thierry of Chartres. Oxford: Oxford University Press.

Almási, Gábor. (2014). Rethinking Sixteenth-Century ‘Lutheran Astronomy’. Intellectual History Review 24 (1): 5-20. 
Axworthy, Angela. 2009. The epistemological foundations of the propaedeutic status of mathematics according to the epistolary and prefatory writings of Oronce Finé. In The worlds of Oronce Fine. Mathematics, instruments and print in Renaissance France, ed. A. Marr, 31-51. Donington: S. Tyas.

- 2016. Le Mathématicien renaissant et son savoir. Le statut des mathématiques selon Oronce Fine. Classiques Garnier.

Ayala, Jorge M. 1993. El Maestro Darocense Pedro Sánchez Ciruelo. Aragón en la Edad Media 10-11:85-99. Zaragoza: Universidad de Zaragoza.

Barker, Peter. 2011. The reality of Peurbach's orbs: Cosmological continuity in fifteenth and sixteenth century astronomy. In Change and continuity in early modern cosmology, ed. Patrick J. Boner, 7-32. Heidelberg/London/New York: Springer.

Bataillon, Marcel. 1966. Erasmo y España. Madrid: Fondo de Cultura Económica. (French original: Erasme et l'Espagne. Recherches sur l'histoire spirituelle du XVIe siècle, first ed. 1937).

Beltrán de Heredia, Vicente. 1972. Cartulario de la Universidad de Salamanca. Salamanca: Universidad de Salamanca.

Biagioli, Mario. 1989. The social status of Italian mathematicians, 1450-1600. History of Science 27: 41-95.

-1993. Galileo courtier. The practice of science in the culture of absolutism. Chicago: The University of Chicago Press.

Blair, Ann, and Anthony Grafton. 1992. Reassessing humanism and science. Journal of the History of Ideas 53 (4): 535-540.

Boll, Franz. 1894. Studien über Claudius Ptolemaeus. Ein Beitrag zur Geschichte der griechischen Philosophie und Astrologie. Leipzig: Teubner.

Bouché-Leclercq, Auguste. 1899. L'astrologie grecque. Paris: E. Lerous.

Boudet, Jean-Patrice. 1988. Simon de Phares et l'astrologie a Lyon a la fin du XV siècle. In Lyon, cité de savants. Paris: Éditions du C.T.H.S.

. 1994. Lire dans le ciel: la bibliothèque de Simon de Phares. Bruxelles: Centre d'Étude des Manuscrits.

. 1999. Le Recueil des plus célèbres astrologues de Simon de Phares. Paris: Champion.

Brown, Gary I. 1991. The evolution of the term 'mixed mathematics'. Journal of the History of ideas 52: 81-102.

Burgueño, Susana. 2009. Astronomia, filosofia y humanismo cientifico en Diego de Torres (14821496). Duererías, Analecta Philosophiae. Revista de Filosofía 1: 1-11.

Byrne, James S. 2006. A humanist history of mathematics? Regiomontanus's Padua oration in context. Journal of the History of Ideas 67 (1): 41-61.

Cajori, Florian. 1928. Ciruelo on the names arithmetical and geometrical proportions and progressions. ISIS 10: 363-366.

Calderon, Calixto. 1991. The 16th century Iberian Calculatores. Revista de la Unión Matemática Argentina 35: 245-258.

Caroti, Stefano. 2008. Le fonti medievali delle Disputationes adversus astrologiam divinatricem. In Nello specchio del cielo. Giovanni Pico della Mirandola e le Disputationes contro l'astrologia divinatoria, ed. Marco Bertozzi, 67-93. Florence: Leo S. Olschki.

Celenza, Christopher S. 2004. The lost Italian Renaissance: Humanists, historians, and Latin's legacy. Baltimore: Johns Hopkins University Press.

Cozzoli, Daniele. 2007. Alessandro Piccolomini and the certitude of mathematics. History and Philosophy of Logic 28: 151-171.

Crombie, A.C., and J.D. North. 1970. Roger Bacon. In Dictionary of scientific biography, ed. Ch. Gillispie, vol. I, 377-385. New York: Charles Scribner's Sons.

Crowther, Kathleen, Ashley Nicole McCray, Leila McNeill, Amy Rodgers, and Blair Stein. 2015. The book everybody read: Vernacular translations of Sacrobosco's Sphere in the sixteenth century. Journal for the History of Astronomy 46 (1): 4-28.

Crowther-Heyck, Kathleen. 2003. Wonderful secrets of nature. Natural knowledge and religious piety in reformation Germany. ISIS 94: 253-273. 
De Pace, Anna. 1993. Le matematiche e il mondo: ricerche su un dibattito in Italia nella seconda metà del cinquecento. Milan: Franco Angeli.

Dear, Peter. 1995. Discipline and experience: The mathematical way in the scientific revolution. Chicago: The University of Chicago Press.

- 2001. Revolutionizing the sciences: European knowledge and its ambitions, 1500-1700. Basingstoke: Palgrave.

Desantis, G. 1986. Pico, Pontano e la polemica astrologica. Annali Della Facoltà di Lettere e Filosofia 29: 155-192.

Ebersole, A.V. 1962. Pedro Ciruelo y su Reprobación de hechicerías. Nueva Revista de Filología Hispánica 3/4: 430-437.

Elie, Hubert. 1950-1951. Quelques Maitres de l'université de Paris vers l'an 1500. Archives d'histoire doctrinale et littéraire du Moyen Âge 18: 193-243.

Engammare, Max. 2008. Calendrier des bergers, préface de Max Engammare. Paris: PUF, collection Sources, Fondation Martin Bodmer.

Ernst, Germana. 1991a. Astrology, religion and politics in counter-reformation Rome. In Science, culture and popular belief in Renaissance Europe, ed. S. Pumfrey, P. Rossi, and M. Slawinski, 249-273. Manchester/New York: Manchester University Press.

- 1991b. Religione, ragione e natura. Ricerche su Tommaso Campanella nel tardo Rinascimento. Milan: Franco Angeli.

2001. Veritatis amor dulcissimus: Aspects of Cardano's astrology. In Secrets of nature. Astrology and alchemy in early modern Europe, ed. W. Newman and A. Grafton, 39-68. Cambridge, MA/London: MIT Press.

Faracovi, Ornella Pompeo. 2008a. In difesa dell'astrologia: risposte a Pico in Bellanti e Pontano. In Nello specchio del cielo. Giovanni Pico della Mirandola e le Disputationes contro l'astrologia divinatoria, ed. Marco Bertozzi, 47-66. Firenze: Olschki.

- 2008b. La riforma dell'astrologia, in Il Rinascimento italiano e l'Europa, eds. G.L. Fontana and L. Molà, vol. V, Le scienze, eds. A. Clericuzio, G. Ernst, and M. Conforti, 59-71. Treviso-Costabissara.

- ed. 2012a. Lo Specchio Alto: astrologia e filosofia fra Medioevo e prima età moderna. Pisa: F. Serra.

- 2012b. La polemica antiastrologica di Giovanni Pico della Mirandola. In Il linguaggio dei cieli. Astri e simboli nel Rinascimento, ed. Germana Ernst and Guido Giglioni, 91-107. Rome: Carocci.

Flórez Miguel, Cirilo, Pablo García Castillo, and Roberto Albares Albares. 1988. El humanismo científico. Salamanca: Caja de Ahorros.

- 1989. La ciencia del cielo: astrología y filosofía natural en la Universidad de Salamanca. Salamanca: Caja de Ahorros.

- 1990. Pedro S. Ciruelo: Una enciclopedia humanista del saber. Salamanca: Caja de Ahorros.

Fubini, Ricardo. 2001. L'umanesimo italiano e i suoi storici: Origini rinascimentali-critica moderna. Milan: Franco Angeli.

2006. Humanism and scholasticism: toward an historical definition. In Interpretations of renaissance humanism, ed. Angelo Mazzoco, 127-136. Leiden/Boston: Brill.

Gagné, J. 1969. Du quadrivium aux Scientiae Mediae. In Arts libéraux et philosophie au moyen âge, 975-986. Paris: Vrin.

Galle, Griet. 2003. Peter of Auvergne, questions on Aristotle's De Caelo-A critical edition with an interpretative essay. Leuven: Leuven University Press.

Gómez Martínez, Marta. 2006. Sacrobosco en castellano. Salamanca, Ediciones Universidad de Salamanca.

Gómez Sierra, Esther. 1999. Home and away in Paris: Pedro Sánchez Ciruelo and his Disputatorius dyalogus. In Latin and vernacular in Renaissance Spain, ed. Barry Taylor and Alejandro Coroleu, 83-104. Manchester: Manchester Spanish and Portuguese Studies, Cañada Blanch Centre for Advanced Hispanic Studies. 
2000. Pedagogia y amicitia. Los dialogos latinos de Pedro Ciruelo. In Actas del VIII Congreso de la Asociación Hispánica de Literatura Medieval, ed. M. Freixas and S. Iriso, 843-856. Santander: Asociación Hispánica de Cultura Medieval.

Goulding, R. 2006. Histories of science in early modern Europe. Introduction. Journal of the History of Ideas 67 (1): 33-40.

Grafton, Anthony. 1991. Defenders of the text: The traditions of scholarship in an age of science. Cambridge, MA: Harvard University Press.

1992. Kepler as a reader. Journal of the History of Ideas 53 (4): 561-572.

1997. From Apotheosis to Analysis: Some Late Renaissance Histories of Classical Astronomy. In History and the Disciplines: The Reclassification of Knowledge in Early Modern Europe, ed. Donald R. Kelley. Rochester, 261-76. New York: University of Rochester Press.

- 1999. Cardano's cosmos. The worlds and works of a Renaissance astrologer. Cambridge, MA: Harvard University Press.

Grant, Edward. 1996. Planets, stars, and orbs: The Medieval cosmos, 1200-1687. Cambridge: Cambridge University Press.

Grendler, Paul. 2002. The Italian Renaissance in the past seventy years: Humanism, social history, and early modern in Anglo-American and Italian scholarship. In The Italian Renaissance in the twentieth century, ed. Allen J. Grieco, Michael Rocke, and Fiorella Gioffredi Superbi, 3-24. Florence: Olschki.

Homza, Lou Ann. 1992. Religious humanism, pastoral reform and the Pentateuch in early modern Spain. Pedro Ciruelo's journey from grace to law. PhD Thesis, University of Chicago.

. 1997. Erasmus Hero or heretic Spanish Humanism and the Valladolid assembly of 1527. Renaissance Quarterly 50: 78-118.

- 2000. Religious authority in the Spanish Renaissance. Baltimore/London: The Johns Hopkins University Press.

Jardine, Nicholas. 1984. The birth of history and philosophy of science: Kepler's 'a defence of Tycho against Ursus' with essays on its provenance and significance. Cambridge: Cambridge University Press.

- 1988. Epistemology of the sciences. In The Cambridge history of Renaissance philosophy, ed. C.B. Schmitt, Q. Skinner, E. Kessler, and J. Kraye, 685-711. Cambridge: Cambridge University Press.

- 1998. The places of astronomy in early modern culture. Journal for the History of Astronomy 29: 49-62.

Kirwan, Richard, ed. 2016. Scholarly self-fashioning and community in the early modern university. London/New York: Routledge.

Laird, W.R. 2016. Galileo and the mixed sciences. In Method and order in Renaissance philosophy of nature: The Aristotle commentary tradition, ed. Daniel A. di Liscia and Eckhard Kessler, 253-270. London: Routledge.

Lanuza Navarro, Tayra M.C. 2017. Astrology in court: The Spanish inquisition, authority, and expertise. History of Science 55 (2): 187-209.

Latassa Ortiz, Félix. 1798. Biblioteca nueva de los escritores aragoneses que florecieron desde el año de 1500 hasta 1599. Pamplona: J. Domingo.

Lorente Pérez, J.M. 1921. Biografía y análisis de las obras de matemática pura de Pedro Sánchez Ciruelo. Madrid: Junta para la Ampliación de Estudios.

Mancosu, P. 1992. Aristotelian logic and Euclidean mathematics: Seventeenth-century developments of the Quaestio de Certitudine Mathematicarum. Studies in History and Philosophy of Science 23 (2): 241-265.

- 1996. Philosophy of mathematics and mathematical practice in the seventeenth century. New York/Oxford: Oxford University Press. 
Mandosio, Jean-Marc. 1994. Entre mathématiques et physique: Note sur les 'sciences intermédiaires' à la Renaissance. In Comprendre et maitriser la nature au Moyen Age: Mélanges d'histoire des sciences offerts à Guy Beaujouan, 115-138. Geneve: Droz.

Marr, Alexander, ed. 2009. The worlds of Oronce Fine. Mathematics, instruments and print in Renaissance France. Donington: Shaun Tyas.

Martins, Roberto de Andrade. 2003. Las Fuentes Literarias del Tratado de la esfera de Sacrobosco. In Epistemología e Historia de la Ciencia. Selección de Trabajos de las XIII Jornadas, ed. Víctor Rodríguez and Luis Salvatico, 307-314. Córdoba: Universidad Nacional de Córdoba.

Mateo Ripoll, Verónica. 2002. Sobre una edición ignota de la Reprobación de supersticiones del maestro Ciruelo. Dynamis 22: 437-459.

Mateos Royo, J.A. 1997. Sobre tasas y monedas, ferias y usuras: municipio y mercado en Daroca bajo Juan II y Fernando el Católico (1459-1516). Aragón en la Edad Media 13: 195-216.

- 2002. Municipio y enseñanza pública en Aragón: la escuela de Gramática de Daroca (ss. XVI-XVII). Revista de Historia Moderna 20: 117-148.

Mazzoco, Angelo, ed. 2006a. Interpretations of Renaissance humanism. Leiden/Boston: Brill. . 2006b. Kristeller and the vernacular. In Kristeller reconsidered: Essays on his life and scholarship, ed. John Monfasani, 176-177. New York: Italica Press.

McKirahan, Richard D. 1978. Aristotle's subordinate sciences. The British Journal for the History of Science 11: 197-220.

Molland, George. 1997. Roger Bacon's De laudibus mathematicae. A preliminary study. In Texts and contexts in ancient and Medieval science, ed. Edith Sylla and Michael McVaugh, 68-83. Leiden: Brill.

Moyer, Ann E. 2014. The quadrivium and the decline of Boethian influence. In A companion to Boethius in the Middle Ages, ed. Noel H. Kaylor and Philip E. Phillips, 479-517. Leiden: Brill.

Muñoz Delgado, Vicente. 1964. La lógica nominalista en la Universidad de Salamanca (1510 1530). Madrid: Publicaciones del Monasterio de Poyo.

. 1966. La lógica como scientia sermocinalis en la obra de Pedro Sánchez Ciruelo. Estudios 22: $23-52$.

. 1967. La lógica en Salamanca durante la primera mitad del siglo XVI. Salmanticensis 14: 171-207.

Navarro Brotons, Víctor. 1995. El renacimiento científico (siglo XVI) y la enseñanza de las disciplinas matemáticas en las universidades de Valencia y Salamanca. In II congreso internacional sobre historia de las universidades hispánicas, ed. Mariano Peset, 141-159. Valencia: Universitat de València.

—. 1998. El Renacimiento científico (siglo XVI) y la enseñanza de las disciplinas matemáticas en las Universidades de Valencia y Salamanca. In Doctores y Escolares, ed. J.L. Peset, vol. I, 141-159. Valencia: Universidad de Valencia.

. 2006. The teaching of the mathematical disciplines in sixteenth-century Spain. Science and Education 15: 209-233.

. 2014. Disciplinas, saberes y prácticas: Filosofía natural, matemáticas y astronomía en la sociedad española de la época moderna. Valencia: Universidad de Valencia.

Navarro Brotons, Víctor, Vicente L. Salavert Fabiani, Victoria Roselló Botey, and Víctor Darás Román. 1999. Bibliographia Physico-Mathematica Hispanica. Vol. I, 1475-1600. Valencia: Instituto de Historia de la Ciencia y Documentación ‘López Piñero' Universitat de València-CSIC.

Noreña, Carlos G. 1975. Studies in Spanish renaissance thought. The Hague: M. Nijhoff.

North, John D. 2009. Types of inconsistency in the astrology of Ficino. In Christian Humanism, ed. A. McDonald et al., 281-302. Leiden: Brill.

Oosterhoff, Richard J. 2018. Making mathematical culture: University and print in the circle of Lefèvre d'Étaples. Oxford: Oxford University Press.

Pantin, Isabelle. 1987. La lettre de Melanchton a Simon Grynaeus: Avatars d'une défense de l'astrologie. In Divination et controverse religieuse en France au XVI siècle, ed. R. Aulotte, 85-101. Paris: École normale supérieure de jeunes filles. 
2013. Oronce Finé mathématicien et homme du livre: la pratique éditoriale comme moteur d'évolution. In Mise en forme des savoirs à la Renaissance. À la croisée des idées, des techniques et des publics, ed. Isabelle Pantin and Gérald Péoux, 19-50. Paris: Armand Colin.

Picatoste Rodríguez, F. 1891. Apuntes para una biblioteca científica española del siglo XVI. Madrid: Tello.

Plessis d'Argentré, Charles Du. 1724. Collectio judiciorum de novis erroribus. Vol. I. Paris: Duchesne.

Popper, Nicholas. 2006. Abraham, Planter of Mathematics: Histories of mathematics and astrology in early modern Europe. Journal of the History of Ideas 67 (1): 86-106.

Rabin, Sheila. 1997. Kepler's attitude toward Pico and the anti-astrology polemic. Renaissance Quarterly 50 (3): 750-770.

Rey Pastor, Julio. 1926. Los matemáticos españoles del siglo XVI. Toledo: A. Medina.

Ribeiro do Nascimento, C.A. 1974. Le statut épistémologique des "sciences intermédiaires" selon S. Thomas d Aquin. Cahiers d'Etudes d'Études Médiévales 2: 33-95.

Rinaldi, Michele. 2002. Sic itur ad astra. Giovanni Pontano e la sua opera astrologica nel quadro della tradizione manoscritta della Mathesis di Giulio Firmico Materno. Naples: Loffredo.

Rodrigo Esteban, María Luz. 1999. La ciudad de Daroca a fines de la Edad Media. Selección documental (1328-1526). Daroca: Centro de Estudios Darocenses/Institución Fernando el Católico.

- 2004. Pedro Sánchez Ciruelo y el estudio general de Artes de Daroca. El Ruejo 5: 139-156.

Rodríguez Vidal, R. 1981. Pedro Ciruelo. Darocense (Un intelectual ejemplar). Zaragoza: Institución Fernando el Católico/CSIC.

Serrano Montalvo, Antonio. 1995-1997. La población de Aragón según el Fogaje de 1495. Zaragoza: Institución Fernando el Católico/ Instituto Aragonés de Estadística.

Smoller, Laura A. 1994. History, prophecy, and the stars: The Christian astrology of Pierre D'Ailly, 1350-1420. Princeton, NJ: Princeton University Press.

Tausiet Carles, María. 1992. Religión, ciencia y superstición en Pedro Ciruelo y Martín de Castañega. Revista de Historia Jerónimo Zurita 65-66: 139-147.

Thorndike, Lynn. 1934. A history of magic and experimental science. Vol. IV. New York: Columbia University Press.

- 1941. A history of magic and experimental science. Vol. V. New York: Columbia University Press.

- 1949. The Sphere of Sacrobosco and its commentators. Chicago: The University of Chicago Press.

Thorndike, Lynn, and Pearl Kibre. 1963. A Catalogue of Incipits of Mediaeval Scientific Writings in Latin. Rev. and augm. London: Mediaeval Academy of America.

Valle, Carlos del. 1999. Un poema hebreo de Alfonso de Zamora en alabanza de la versión latina bíblica de Pedro Ciruelo. Sefarad 59 (2): 419-437.

Valleriani, Matteo. 2017. The tracts on the Sphere: Knowledge restructured over a network. In The structures of practical knowledge, ed. Matteo Valleriani, 421-473. Dordrecht: Springer.

Vanden Broecke, Steven. 2003. The limits of influence. Pico, Louvain and the crisis of Renaissance astrology. Leiden/Boston: Brill.

- 2016. From cosmic governance to governmentality: Shaping subulunary order in seventeenth century French critiques of astrology. In Unifying heavens and earth: Essays in the history of early modern cosmology, ed. M.A. Granada, P.J. Boner, and D. Tessicini, 317-342. Barcelona: Universitat de Barcelona.

Vasoli, Cesare. 2008. La polemica antiastrologica di Giovanni Pico. In Nello specchio del cielo. Giovanni Pico della Mirandola e le Disputationes contro l'astrologia divinatoria, ed. Marco Bertozzi, 1-18. Firenze: Olschki.

Villoslada, R.G. 1938. La Universidad de Paris durante los estudios de Francisco de Vitoria, O.P. (1507-1522). Roma: Università Gregoriana.

Voss, Angela. 1998. The music of the spheres: Marsilio Ficino and Renaissance harmonia. Culture and Cosmos 2 (2): 16-38. 
Walker, D.P. 1958. Spiritual and demonic magic. From Ficino to Campanella. London: Warburg Institute.

Wallace, William A. 1969. The Calculatores in early sixteenth-century physics. British Journal for the History of Science 4: 221-232.

. 1981. Chapter. 5: The Calculatores in the sixteenth century. In Prelude to Galileo. Essays on Medieval and sixteenth century sources of Galileo's thought, 78-90. Dordrecht: Reidel.

Westman, Robert S. 1980. The astronomer's role in the sixteenth century: A preliminary study. History of Science 18: 105-147.

- 2011. The Copernican question. Prognostication, skepticism, and celestial order. Berkeley/Los Angeles: University of California Press.

- 2016. Copernicus and the astrologers: Dibner library lecture, December 12, 2013. Washington, DC: Smithsonian Libraries.

Wilkinson, Alexander S. 2010. Iberian books: Books published in Spanish or Portuguese or on the Iberian Peninsula before 1601. Leiden/Boston: Brill.

Zambelli, Paola, ed. 1986. Astrology Hallucinati: Stars and the end of the world in Luther's time. Berlin: W. de Gruyter.

- 1992. The Speculum astronomiae and its enigma: Astrology, theology, and science in Albertus Magnus and his contemporaries. Dordrecht/Boston: Kluwer.

. 1994. Una reincarnazione di Pico ai tempi di Pomponazzi. Milan: Il Polifilo.

Zamora Calvo, M.J. 2008. Ciruelo y sus juicios contra la superstición. In La fractura historiográfica: las investigaciones de Edad Media y Renacimiento desde el Tercer Milenio, ed. Javier San José Lera et al., 781-797. Salamanca: Seminario de Estudios Medievales y Renacentistas.

Open Access This chapter is licensed under the terms of the Creative Commons Attribution 4.0 International License (http://creativecommons.org/licenses/by/4.0/), which permits use, sharing, adaptation, distribution and reproduction in any medium or format, as long as you give appropriate credit to the original author(s) and the source, provide a link to the Creative Commons license and indicate if changes were made.

The images or other third party material in this chapter are included in the chapter's Creative Commons license, unless indicated otherwise in a credit line to the material. If material is not included in the chapter's Creative Commons license and your intended use is not permitted by statutory regulation or exceeds the permitted use, you will need to obtain permission directly from the copyright holder.

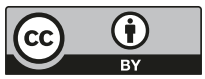

